\title{
O MinistÉRIO PÚblico BRASILEIRO \\ E O ADVOGADO GERAL DO TRIBUNAL DE \\ JUSTIÇA DA UNIÃO EUROPEIA: \\ UMA BREVE COMPARAÇÃO
}

\author{
PETER SESTER ${ }^{\dagger}$ \\ ANDREIA CRISTINA DE OLIVEIRA ${ }^{\dagger \dagger}$
}

RESUMO: Este artigo discorre sobre os institutos do Ministério Público do Brasil e do Advogado Geral do Tribunal de Justiça da União Europeia, por meio de comparação entre os dois; considerando o contexto jurídico, histórico e político-cultural em que cada um está inserido. Para isso, inicialmente, serão abordadas as características da instituição brasileira; em seguida as de sua contraparte europeia; para, por fim, serem traçados paralelos, no que se refere à sua origem histórica e modo de operação similar, bem como os contrastes encontrados. Buscaremos, assim, compreender como duas instituições, que se originaram a partir da mesma figura do direito francês, foram adaptadas para as necessidades do meio em se desenvolveram.

Palavras-Chave: Ministério Público; Advogado Geral; Tribunal de Justiça da União Europeia.

\footnotetext{
† Catedrático da Cadeira Lemann de Direito Comercial Internacional e Law \& Economics, e Diretor do Instituto de Finanças Públicas, Direito Fiscal e Law \& Economics, da University of St. Gallen, Suíça.

† Graduanda em Direito pela Universidade Presbiteriana Mackenzie.
} 
ABStraCT: This article compares the institutes of the Ministério Público of Brazil and the Advocate General of the Court of Justice of the European Union; considering the legal, historical, and political-cultural frameworks in which each is inserted. To do so, we will first discuss the characteristics of the Brazilian institution, then its European counterpart's. In order to determine parallels, regarding their similar historical background and mode of operation, as well as, the contrasts found. Thus, we will attempt to understand how the two institutions, both incorporated from the same French law entity, were adapted to the needs of the environment in which they were developed.

KeYWORDS: Ministério Público; Advocate General; Court of Justice of the European Union. 


\section{SUMÁRIO:}

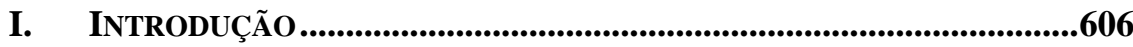

II. O MINISTÉRIO PÚBLICO NO BRASIL .................................................607

1. Origem Histórica do Ministério Público..............................607

2. Conceitos Gerais ................................................................608

3. A Estrutura do Ministério Público ...................................611

4. Garantias e Vedações Constitucionais ................................613

5. Funções do Ministério Público........................................615

6. Imparcialidade e Defesa do Povo.......................................618

7. O Parecer do Ministério Público ......................................619

III. O AdVOGAdo GERAL do TRIBUNAL DE JUSTIÇA

DA UNIÃO EUROPEIA ...............................................................621

1. A Formação da União Europeia.......................................621

2. O Tribunal de Justiça da União Europeia .......................623

3. Procedimentos do Tribunal de Justiça ..............................626

4. Os Juízes do Tribunal de Justiça da União Europeia ......628

5. Advogados Gerais.........................................................629

IV. COMPARAÇÕES ................................................................................638

1. Diferentes Conceitos de Estado Democrático .......................638

2. O Tribunal de Justiça da União Europeia e os Tribunais Superiores do Brasil.................................641

3. O Advogado Geral e o Procurador do Ministério Público 641

V. CONCLUSÕES...............................................................................643

VI. REFERÊNCIAS ................................................................643 
TABLE OF CONTENTS:

I. INTRODUCTION .........................................................................606

II. THE MINISTÉRIO PÚBLICO IN BRAZIL .............................................607

1. Historical Origin of the Ministério Público ..........................607

2. General Concepts.....................................................................608

3. The Structure of the Ministério Público ...........................611

4. Constitutional Guarantees and Prohibitions .......................613

5. Functions of the Ministério Público ................................615

6. Impartiality and Defense of the People..............................618

7. The Opinion of the Ministério Público..............................619

III. THE ADVOCATE GENERAL

OF THE COURT OF JUSTICE OF THE EUROPEAN UNION .................621

1. The European Union Formation ..................................621

2. The Court of Justice of the European Union ...................623

3. Procedures of the Court of Justice.......................................626

4. The Judges of the Court of Justice of the European Union .................628

5. Advocates General.................................................................629

IV. COMPARISONS..................................................................................6638

1. Different Concepts of Democratic State...............................638

2. The Court of Justice of the European Union and the Brazilian Superior Courts ....................................641

3. The Advocate General and the Prosecutor of the Ministério Público ......................641

V. CONCLUSIONS .........................................................................643

VI. REFERENCES .....................................................................643 


\section{INTRODUÇÃO}

Alguns autores, como Hugo Mazzilli, explicam a instituição do Ministério Público (ou MP) como uma reação ao crescente poder da Justiça. Finda a Idade Média, com o nascimento e a crescente complexidade do Estado, os soberanos começaram a instituir tribunais regulares para distribuir a Justiça em seu nome. Para compensar a autonomia dos tribunais, que às vezes contrariavam os interesses da Coroa, os reis instituíram seus procuradores para promover a defesa de seus interesses junto a essas cortes. Atualmente, os membros do Ministério Público exercem suas funções inseridos no sistema de freios e contrapesos, cujo objetivo é evitar abusos de um dos Três Poderes (Executivo, Legislativo e Judiciário) sobre o outro, e manter o equilíbrio.

Com a adaptação da instituição ao Estado moderno, o objetivo do Ministério Público mudou: os procuradores não defendem mais os interesses do rei, mas sim os interesses do Estado. Entretanto, para limitar ou equilibrar o poder do Ministério Público é necessário esclarecer o isso significa. O MP, por si só, não pode definir o que é de interesse do Estado, pois, em uma democracia, esse é um direito do povo e do legislador. Assim, interesse do Estado, com relação ao Ministério Público, significa defender e fiscalizar as leis e as normas do país. Temos como exemplo a atuação do Ministério Público Federal nas investigações da operação Lava-Jato, em que a função de defender e fiscalizar a lei perante todos tem uma significativa importância para a manutenção do sistema de freios e contrapesos. $\mathrm{O}$ foco da investigação Lava-Jato não é somente o mau comportamento do setor privado, mas também o mau comportamento de membros do Poder Legislativo.

Naturalmente, a existência e a relevância do Ministério Público em cada Estado dependem também de sua população e da visão que esta tem do próprio Estado. A constituição de cada país é um bom reflexo da percepção do povo, que também depende de aspetos históricos, culturais e econômicos de cada sociedade. Para ilustrar, ao longo deste

trabalho veremos os diferentes conceitos de Estado no Brasil, França e Suiça, o que nos ajudará a entender as singularidades da União Europeia.

Durante a formação da União Europeia (ou UE), a delegação francesa fez a proposta de integrar ao sistema judiciário europeu, uma instituição à semelhança do seu Ministério Público, que tivesse o dever de assegurar a boa aplicação das leis da União. Contudo, a função do procurador do Estado francês não poderia ser traduzida literalmente para o direito Europeu. Até porque a União Europeia não é um Estado, mas uma organização, um organismo, com seu sistema legal próprio. $\mathrm{O}$ 
direito da União Europeia tem uma importância extraordinária para a sua própria existência, porque somente este direito garante que a UE se torne independente da política do dia-a-dia dos Estados membros.

Grande parte do direito europeu vincula apenas seus EstadosMembros, o que impossibilita que os cidadãos Europeus cobrem a efetiva aplicação dessas leis por meio de ações judiciais. Consequentemente, faz-se necessária uma instituição que, pelo menos em alguns aspectos, seja comparável ao Ministério Público do Brasil ou da França. Na União Europeia há dois órgãos que exercem essas funções: a Comissão Europeia e os advogados gerais no Tribunal de Justiça da União Europeia (ou TJUE). Enquanto a Comissão pode tomar a iniciativa e processar Estados-Membros ou órgãos da União Europeia, os advogados gerais não podem tomar esta iniciativa, mas opinam nos casos dos processos que chegam ao Tribunal de Justiça europeu em Luxemburgo.

O trabalho a seguir visa explorar essas semelhanças e contrastes entre o direito brasileiro e o direito europeu, sob o enfoque destas duas instituições com funções comparáveis, apesar de cenários tão diferentes: um estado federativo e um bloco econômico. Por meio de pesquisa em literatura brasileira, europeia e americana, veremos que diversos fatores influenciaram suas estruturas legais, sobretudo seu contexto histórico e cultura local, que moldam as necessidades específicas de cada um.

\section{O MinistÉRIO PÚBLICO NO BRASIL}

\section{Origem Histórica do Ministério Público}

A formação histórica do Ministério Público é um dos pontos que nos permite a comparação com o advogado geral da União Europeia, uma vez que ambos têm raízes no direito francês. No caso do Ministério Público, o mais comum é conferir a origem do instituto aos procuradores do rei da antiga França ${ }^{1}$. A Revolução Francesa, ao conferir garantias a seus integrantes, estruturou mais adequadamente o Ministério Público enquanto instituição. Foram, porém, os textos napoleônicos que instituíram o Ministério Público que a França veio a conhecer na atualidade, servindo como modelo para vários Estados modernos. O MP brasileiro evoluiu a partir do direito lusitano, ainda que na França tenha surgido contemporaneamente a Portugal.

${ }^{1}$ MAZZILLI, Hugo Nigro. Introdução ao Ministério Público. São Paulo, SP: Saraiva, 2015, p. 39.

2 JOURNAL OF INSTITUTIONAL STUDIES 2 (2016) 
O conceito atribuído pela legislação francesa, e a visão do seu povo sobre o Estado, favorecem claramente a emergência e o poder de uma instituição que toma conta do interesse do Estado. O conceito do Estado brasileiro e a cultura brasileira assemelham-se ao Estado e à cultura francesa, que favorecem um papel forte do Estado na sociedade e na economia. Um exemplo recorrente que pode ser usado para ilustrar esta ideia é o caso da Petrobras. Trata-se empresa estatal de economia mista, que o povo brasileiro, de modo geral, não quer privatizar $^{2}$, apesar dos repetidos escândalos de corrupção no governo em sua relação com a empresa. Por isso, pode-se dizer que o grande poder conferido ao Estado no Brasil foi inspirado no modelo francês, afinal, são dois povos cuja visão cultural permite a existência de uma instituição forte, como é o Ministério Público, com a prerrogativa de defender o interesse do Estado em um sentido amplo.

Adicionalmente, a Constituição de 1988 - um documento muito extenso comparado a outras constituições - foi uma reação ao regime militar, o que fortaleceu o Ministério Público brasileiro com relação à Justiça. Vale ressaltar que os juízes da época da ditadura não foram exonerados de seus cargos, como aconteceu com os juízes do partido comunista da antiga Alemanha, após a unificação. Desta forma, o fortalecimento do Ministério Público brasileiro foi um passo importante para o processo de democratização. Outro fator que permite e justifica a existência do Ministério Público, com a força que tem, é o fato de que grande parcela da população brasileira não tem os conhecimentos ou os recursos para defender os próprios direitos na Justiça. Assim, faz-se necessária uma instituição cujo dever seja defender os interesses da coletividade.

\section{Conceitos Gerais}

A Constituição de 1988 (ou CF) apresenta, no Título IV, Capítulo IV, o que denominou Funções Essenciais à Justiça. Lá foram alocados cargos e órgãos que atuam perante o Poder Judiciário, sem, no entanto, integrálo. Exercem funções essenciais à justiça: o Ministério Público, a advocacia pública, a defensoria pública e a advocacia privada. A

${ }^{2}$ Em 17 de março de 2015, a Gerência de Pesquisas de Opinião do Datafolha publicou uma pesquisa que verificou que $61 \%$ dos brasileiros são contrários à privatização da Petrobras. Disponível em:

$<$ http://media.folha.uol.com.br/datafolha/2015/03/23/imagem-da-petrobras-site.pdf $>$. Acesso em: 19 set. 2016.

2 JOURNAL OF INSTITUTIONAL STUDIES 2 (2016) 
atuação dessas pessoas ou órgãos é imprescindível ao próprio exercício da função jurisdicional, tendo em conta, sobretudo, o fato de que o Poder Judiciário não atua de ofício. A necessidade de provocação ao Poder Judiciário, garante o equilíbrio entre os Três Poderes e também sua imparcialidade.

O Ministério Público é instituição permanente, essencial à função jurisdicional do Estado, incumbindo-lhe a defesa da ordem jurídica, do regime democrático e dos interesses sociais e individuais indisponíveis (CF, art. 127). De forma geral, é o órgão que possui capacidade postulatória e atua em juízo na defesa dos interesses gerais da população. É titular da ação penal pública e foi investido de diversas outras competências fundamentais para a proteção da sociedade ${ }^{3}$. A finalidade institucional do Ministério Público é própria, inconfundível com as das demais carreiras jurídicas. Além disso, diversos dispositivos esparsos asseguram garantias gerais às instituições, conferindo ao Ministério Público status de mesmo nível da Magistratura ${ }^{4}$.

$\mathrm{O}$ texto constitucional também se encarregou de positivar princípios institucionais que devem reger a forma como os membros do Ministério Público devem exercem suas funções e quais autonomias a ele devem ser garantidas. Do art. 127, $\S 1^{\circ}$ da Constituição Federal, temos que os princípios institucionais do Ministério Público são a unidade, a indivisibilidade e a independência funcional.

O Ministério Público é considerado uno, na medida em que compõe um só corpo institucional orientado para o interesse púbico e bem comum, da nação pro populo e não do Estado pro domo sua. Daí decorre a sua indivisibilidade ou substituição de seus membros uns pelos outros. Quando atua um integrante da instituição é a instituição inteira que se manifesta $^{5}$. Este princípio se aplica dentro de cada instância do Ministério Público, o que significa dizer que não há unidade entre o Ministério Público da União e os Ministérios Públicos dos Estados. As investiduras são próprias de cada ente, assim como os demais atributos de sua autonomia administrativa, orçamentária, financeira e funcional.

O princípio da indivisibilidade é derivado do princípio da unidade, pois a unidade do Ministério Público está também representada pelo

${ }^{3}$ PAULO, Vicente; ALEXANDRINO, Marcelo. Direito Constitucional Descomplicado. São Paulo, SP: Método, 2010, p. 704.

${ }^{4}$ MAZZILLI, Hugo Nigro. Introdução ao Ministério Público. São Paulo, SP: Saraiva, 2015, p. 128.

${ }^{5}$ SAMPAIO, José Adércio Leite. In: Joaquim José Gomes Canotilho; Gilmar Ferreira Mendes; Ingo Wolfgang Sarlet; Lenio Luiz Streck. Comentários à Constituição do Brasil. São Paulo, SP: Saraiva/Almedina, 2013, p. 1521. 
impedimento à subdivisão em outros Ministérios Públicos autônomos e desvinculados uns dos outros. A atuação dos membros do Ministério Público é a atuação do próprio órgão, indivisível por disposição constitucional expressa. Este princípio traduz-se na não vinculação dos membros do Ministério Público aos processos em que atuam, podendo ser substituídos uns pelos outros, sem prejuízo ao processo.

A independência funcional se aplica à instituição como um todo (independência externa ou orgânica) e a cada membro individualmente (independência interna). Destarte, o Ministério Público é independente no exercício de suas funções, não está subordinado a qualquer dos Três Poderes; e seus membros não se subordinam a quem quer que seja, nem mesmo a seus superiores hierárquicos, haja vista que a relação de subordinação entre eles é meramente administrativa e não de ordem funcional.

A atuação do Ministério Público deve estar sempre vinculada à busca existencial do bem comum, tanto no atendimento do interesse social, quanto na proteção dos direitos fundamentais. Tem a incumbência da própria democracia e deve prestar contas de suas tarefas difusamente à sociedade e aos cidadãos; e organicamente às estruturas de controle interno, externo e misto.

Ao Ministério Público é assegurado, constitucionalmente, o autogoverno, através da autonomia administrativa, orçamentária, financeira e funcional. Sujeita-se, entretanto, a controles interorgânicos, como a investidura do Procurador Geral, a possibilidade de sua destituição, a relativa discricionariedade legislativa de concretização das normas constitucionais que definem sua feição institucional, o controle externo previsto constitucionalmente ${ }^{6}$ e o caráter misto realizado pelo Conselho Nacional do Ministério Público ${ }^{7}$.

Quanto à autonomia administrativa, esta confere ao Ministério Público poderes para, observados os limites estabelecidos em lei, propor ao Poder Legislativo a criação e extinção de seus cargos e serviços

\footnotetext{
${ }^{6}$ Constituição da República Federativa do Brasil de 1988, Art. 71: “O controle externo, a cargo do Congresso Nacional, será exercido com o auxílio do Tribunal de Contas da União, a qual compete (...)".

${ }^{7}$ Constituição da República Federativa do Brasil de 1988, Art. 130-A, §2으: "Compete ao Conselho Nacional do Ministério Público o controle da atuação administrativa e financeira do Ministério Público e do cumprimento dos deveres funcionais de seus membros, cabendo lhe: I - zelar pela autonomia funcional e administrativa do Ministério Público, podendo expedir atos regulamentares, no âmbito de sua competência, ou recomendar providências".
} 
auxiliares. No exercício desta autonomia, o Ministério Público elabora suas próprias folhas de pagamento; adquire bens e contrata serviços; edita atos de concessão de aposentadoria, exoneração de seus servidores, etc.

A autonomia financeira - garantida pela norma inscrita no art. 168 da Constituição, outorga ao Ministério Público a competência para elaborar sua proposta orçamentária, dentro dos limites e prazos estabelecidos na lei de diretrizes orçamentárias. Todavia, não pode a lei prever que o próprio órgão elabore seu orçamento, devendo essa proposta integrar-se ao orçamento geral que será submetido ao Poder Legislativo pelo chefe do Poder Executivo. Assim, o Ministério Público não possui recursos próprios, mas, na elaboração da proposta do orçamento geral, tem o poder de indicar os recursos necessários a atender às suas próprias despesas.

Por fim, a autonomia do Ministério Público está assentada, também, na outorga ao Procurador Geral da República e aos Procuradores Gerais de Justiça da iniciativa de lei sobre a organização, respectivamente, do Ministério Público da União e dos Estados ( $\mathrm{CF}$, art. $128 \S 5^{\circ}$ ). Essa iniciativa, porém, será exercida concorrentemente com o chefe do Poder Executivo, segundo a disposição constitucional ${ }^{8}$.

\section{A Estrutura do Ministério Público}

Integram o Ministério Público: o Ministério Público da União, que, sob chefia do Procurador Geral da República, compreende o Ministério Público Federal; o Ministério Público do Trabalho; o Ministério Público Militar; o Ministério Público do Distrito Federal e Territórios; e o Ministério Público dos Estados.

O Estatuto do Ministério Público deve ser previsto em lei complementar federal e dos Estados. Em vista da fonte legal constitucionalmente prevista, não há de ser tratada pelo constituinte

${ }^{8}$ Constituição da República Federativa do Brasil de 1988, Art. 61, caput: “A iniciativa das leis complementares e ordinárias cabe a qualquer membro ou Comissão da Câmara dos Deputados, do Senado Federal ou do Congresso Nacional, ao Presidente da República, ao Supremo Tribunal Federal, aos Tribunais Superiores, ao ProcuradorGeral da República e aos cidadãos, na forma e nos casos previstos nesta Constituição. $\S 1^{\circ}$ São de iniciativa privativa do Presidente da República as leis que: (...) II disponham sobre: (...) d) organização do Ministério Público e da Defensoria Pública da União, bem como normas gerais para a organização do Ministério Público e da Defensoria Pública dos Estados, do Distrito Federal e dos Territórios; (...)". 
decorrente ${ }^{9}$. No âmbito da União, aplica-se a Lei Complementar $\mathrm{n}^{\mathrm{o}}$ 75/1993; ao Ministério Público dos Estados, a Lei Orgânica Nacional no 8625/1993; por fim, cada estado da federação tem o seu Ministério Público, organizado nos termos da respectiva lei complementar estadual. Considerando as peculiaridades de cada ente federativo, a Constituição faculta aos respectivos Procuradores Gerais, da República e de Justiça, a sua iniciativa, exercida e evidentemente perante o Poder Legislativo próprio, definido a organização, as atribuições e o estatuto de cada Ministério Público.

O Procurador Geral da República exerce a chefia do Ministério Público da União e do Ministério Público Federal, além de atuar como Procurador Geral Eleitoral. É escolhido e nomeado pelo presidente da República, e seu nome deve ser aprovado pela maioria absoluta do Senado Federal. Segundo prevê a Constituição Federal, o Procurador Geral da República deve sempre ser ouvido nas ações de inconstitucionalidade e nos processos de competência do Supremo Tribunal Federal (ou STF).

O Procurador Geral da República pode promover ação direta de inconstitucionalidade e ações penais para denunciar autoridades como deputados federais, senadores, ministros de Estado e o presidente e o vice-presidente da República. Ele tem a prerrogativa de representar, perante o Supremo Tribunal Federal, pela intervenção nos Estados e no Distrito Federal na hipótese do art. 34, inciso VII, da Constituição Federal e no caso de recusa à execução de lei federal (CF, art. 36, III). Também pode, perante o Superior Tribunal de Justiça, propor ação penal e representar pela federalização de casos de crimes contra os direitos humanos.

O Procurador Geral de Justiça é nomeado pelo governador do Estado dentre os integrantes vitalícios e em atividade na carreira, indicados em lista tríplice formada pelos candidatos mais votados, para mandato de dois anos, permitida uma recondução. Compete ao Procurador Geral de Justiça, em destaque: exercer a chefia do Ministério Público, representando-o judicial e extrajudicialmente; integrar, como membro nato, e presidir o Colégio de Procuradores de Justiça, o Conselho Superior do Ministério Público e a Comissão de Concurso; encaminhar ao Poder Legislativo os projetos de lei de iniciativa do Ministério Público; propor ao Colégio de Procuradores de Justiça a fixação das atribuiçõ̃es das Procuradorias e Promotorias de Justiça; e apresentar o plano geral de atuação do Ministério Público destinado a

9 STF, ADI 2.622/RO-MC, Min. Rel. Sydney Sanches, Tribunal Pleno. Julgamento em: $08 / 08 / 2002$.

2 JOURNAL OF INSTITUTIONAL STUDIES 2 (2016) 
viabilizar a consecução de metas prioritárias nas diversas áreas de suas atribuições.

Adicionalmente, também são atribuições do Procurador Geral de Justiça: representar aos Tribunais locais por inconstitucionalidade de leis ou atos normativos estaduais ou municipais, face à constituição estadual; representar para fins de intervenção do Estado no Município, com o objetivo de assegurar a observância de princípios indicados na Constituição Estadual ou prover a execução de lei, de ordem ou de decisão judicial; representar o Ministério Público nas sessões plenárias dos Tribunais; ajuizar ação penal de competência originária dos Tribunais, nela oficiando; determinar o arquivamento de representação, notícia de crime, peças de informação, conclusão de comissões parlamentares de inquérito ou inquérito policial, nas hipóteses de suas atribuições legais; representar ao Procurador Geral da República para fins de intervenção da União no Estado, nas hipóteses previstas no art. 34, inciso VII, da Constituição Federal.

\section{Garantias e Vedações Constitucionais}

As garantias constitucionais expressas estão previstas no art. 128, $\S$ $5^{\circ}$, inciso I e sua a maioria tem a finalidade de proteger a independência de atuação e estímulo à carreira, como a vitalidade, a inamovibilidade, irredutibilidade de subsídio, a aposentadoria e a prerrogativa de foro. Fora estas, temos a garantia à reserva de vagas nos tribunais, que se volta mais para a atribuição de caráter plural à composição dos órgãos judiciários colegiados, com a reserva de algumas de suas vagas aos membros ministeriais.

Majoritariamente, o Supremo Tribunal Federal tem reconhecido a garantia constitucional implícita do promotor natural. $\mathrm{O}$ que significa que o promotor ou o procurador não pode ser designado sem obediência ao critério legal, a fim de garantir julgamento imparcial. Veda-se, assim, designação de promotor ou procurador ad hoc, no sentido de fixar prévia orientação, assim como seria inimaginável a indicação singular de magistrado para processar e julgar alguém. É de fundamental importância que se fixe previamente o critério de designação. O Superior Tribunal de Justiça também já se posicionou sobre o tema, chegando à conclusão de que o réu tem direito público, 
subjetivo de conhecer o órgão do Ministério Público, como ocorre com o juízo natural ${ }^{10}$.

José Sampaio, em seus comentários à Constituição Federal ${ }^{11}$, chama de garantias constitucionais por remissão aquelas que decorem da disposição do art. 129, § $4^{\circ}$, CF, que prevê que "no que couber", ou seja, tendo em vista as particularidades de estrutura e funcionamento e requerendo adaptações, devem-se aplicar ao Ministério Público as garantias da Magistratura dispostas no art. 93 da Carta Magna. Dentre as quais: ingresso na carreira mediante concurso público de provas e títulos, políticas de aperfeiçoamento profissional, política de promoção; política de movimentação; política de remuneração por meio de subsídio; e atividade ministerial ininterrupta e ágil.

Outrossim, a Constituição traçou algumas vedações destinadas a assegurar uma atuação livre de coações e da influência sobranceira de interesses provados sobre a finalidade institucional. Estão listadas proibições remuneratórias e profissionais, além de restrições de domicílio.

É vedado aos membros do Ministério Público, em relação à remuneração adicional: o recebimento, a qualquer título e sob qualquer pretexto, de honorários, percentagens ou custas processuais; a percepção, a qualquer título ou pretexto, de auxílios ou contribuições de pessoas físicas, entidades públicas ou provadas, ressalvadas as exceções previstas em lei.

O art. 44 da Lei nº 8.625/93 e o art. 128, § 5\%, inciso II da Constituição Federal, arrolam as vedações aos membros do Ministério Público, que, nestes termos, ficam proibidos de exercer o comércio em nome individual, ou participar de sociedades mercantis que não revistam a forma de sociedades por cotas ou por ações. Enquanto cotistas ou acionistas, não podem participar da administração do empreendimento, estão autorizados apenas a participar da escolha dos dirigentes, e a compor órgãos de fiscalização. Também não podem exercer, ainda que em disponibilidade, de qualquer outra função pública, salvo uma de magistério. Ademais, o membro do parquet tem restrita a sua liberdade de domicílio, considerando que deve ter residência na comarca da respectiva lotação, salvo quando autorizado pelo chefe da instituição.

${ }^{10}$ STJ, REsp 11.722/SP, Min. Rel. Luiz Vicente Cernicchiaro, Sexta Turma. Julgamento em: 08/09/1992.

${ }^{11}$ SAMPAIO, José Adércio Leite. In: Joaquim José Gomes Canotilho; Gilmar Ferreira Mendes; Ingo Wolfgang Sarlet; Lenio Luiz Streck. Comentários à Constituição do Brasil. São Paulo, SP: Saraiva/Almedina, 2013, p. 1528. 


\section{Funções do Ministério Público}

A Constituição de 1988 ampliou as funções do Ministério Público, elevando-o a condição de defensor da sociedade, nas esferas penal e cível, e incumbindo-o de zelar pela moralidade e probidade administrativas. Além disso, podemos influir do art. 129, inciso IX ${ }^{12}$, que essa enumeração de competências não é exaustiva, podendo outras competências serem outorgadas ao Ministério Público pelo legislador, desde que sejam compatíveis com a missão constitucional do órgão.

O texto constitucional defere ao Ministério Público o dominus litis da ação penal pública, o zelo pelo efetivo respeito dos poderes públicos e dos serviços de relevância pública aos direitos assegurados na Constituição, fazendo uso das medidas necessárias a sua garantia. Também é de sua competência a promoção do inquérito civil e da ação civil pública para proteção do patrimônio público e social, do meio ambiente e de outros interesses difusos e coletivos. Bem como the atribui legitimidade para, concorrentemente, propor ação de inconstitucionalidade e, privativamente, no plano federal, a representação para fins de intervenção da União nos Estados. O papel de custos legis societatis se completa com a defesa dos direitos e interesses das populações indígenas e o controle externo da atividade policial, esta submetida à disciplina da lei complementar.

Esse conjunto de atribuições pode exigir do Ministério Público uma atuação ativa, como parte, ou uma atuação imparcial, de magistratura, pura e simples, na fiscalização de certa aplicação da lei em conformidade com a Constituição. A atuação imparcial bem demonstra a particularidade da função ministerial. Como custos legis, tem entendido o Supremo Tribunal Federal, o Ministério Público ocupa "posição de grande eminência no contexto da relação processual, incumbindo-lhe o desempenho imparcial da atividade fiscalizadora pertinente à correta aplicação do Direito objetivo"13, possibilitando tratamento processual diferenciado, a exemplo da conferência de prerrogativa de prazo ilimitado para sustentação oral.

${ }^{12}$ Constituição da República Federativa do Brasil de 1988, Art. 129, IX: “Exercer outras funções que lhe forem conferidas, desde que compatíveis com sua finalidade, sendolhe vedada a representação judicial e a consultoria jurídica de entidades públicas". ${ }_{13}$ STF, ADI 2.314/RJ, Min. Rel. Moreira Alves, Tribunal Pleno. Julgamento em: $25 / 04 / 2001$.

2 JOURNAL OF INSTITUTIONAL STUDIES 2 (2016) 
Como parte em processos administrativos e judiciais, o Ministério Público executa tarefas de grande alcance social e político. À sua tradicional função de titular da ação penal pública, alia-se a missão de salvaguarda dos direitos difusos e coletivos numa síntese constitucional elogiável ${ }^{14}$. A titularidade privativa da ação penal pública, entretanto, não recepcionou disposições legais que conferiam a legitimidade ativa da ação penal pública a outras pessoas como magistrados, autoridades policiais e demais agentes administrativos ${ }^{15}$.

Essa exclusividade não alcança, porém, todos os poderes de ativação e desenvolvimento da relação jurídico-processual penal de terceiros. Lembremos, pelos primeiros, a legitimação subsidiária do ofendido para ajuizamento da ação penal pública ${ }^{16}$ e, pelos segundos, a apelação supletiva prevista pelo Código de Processo Penal ${ }^{17}$. É de se notar, portanto, que a ocorrência de tais poderes só incide no caso de inércia do parquet, de modo que não pode haver modificação, ampliação ou correção da atividade do titular da ação penal. Interessante ainda observar que o arquivamento de inquérito policial pelo Procurador Geral da República, dada a sua peculiar situação de chefe da instituição, é acolhido pelo Supremo Tribunal Federal.

As questões de direito coletivo, temário indispensável do Direito do século XXI, surgem das complexidades de estruturas sociais heterogêneas de nosso tempo e desafiam uma proteção efetiva, não só por meio de políticas públicas, mas também de instrumentos processuais de tutela, sendo necessária adaptação dos convencionais mecanismos do processo, sobretudo por meio de uma legitimidade ativa alargada, como reconhece o art. 129 ao conferir legitimidade ao

${ }^{14}$ SAMPAIO, José Adércio Leite. In: Joaquim José Gomes Canotilho; Gilmar Ferreira Mendes; Ingo Wolfgang Sarlet; Lenio Luiz Streck. Comentários à Constituição do Brasil. São Paulo, SP: Saraiva/Almedina, 2013, p. 1532.

${ }_{15}$ STF, HC 67.931/RS, Min. Rel. Moreira Alves, Tribunal Pleno. Julgamento em: 10/04/1990; STF, RE 134.515/ES, Min. Rel. Carlos Velloso, Segunda Turma. Julgamento em: 13/08/1991; STF, HC 72.073/, Min. Rel. Carlos Velloso, Segunda Turma. Julgamento em: 02/04/1996.

${ }^{16}$ Constituição da República Federativa do Brasil de 1988, Art. 5º, LIX: "Será admitida ação privada nos crimes de ação pública, se esta não for intentada no prazo legal". ${ }^{17}$ Código de Processo Penal, Decreto-Lei no 3.689/1941: “Art. 598. Nos crimes de competência do Tribunal do Júri, ou do juiz singular, se da sentença não for interposta apelação pelo Ministério Público no prazo legal, o ofendido ou qualquer das pessoas enumeradas no art. 31, ainda que não se tenha habilitado como assistente, poderá interpor apelação, que não terá, porém, efeito suspensivo".

2 JOURNAL OF INSTITUTIONAL STUDIES 2 (2016) 
Ministério Público para promover determinadas ações civis sem impedir a legitimidade de terceiros.

A função do Ministério Público nesse domínio é o que concretiza seu caráter de órgão estatal, para situá-lo em uma zona de comunicação entre o sistema do Estado e o sistema social. É visto, assim, numa relação conflitosa, ora em relação à sociedade, na realização de valores objetivos; ora em relação ao Estado, em face de omissões e de ações que violem direitos constitucionais e legais. Nessa linha, o Supremo Tribunal Federal reconheceu a legitimidade do Ministério Público para ajuizamento de ação civil pública destinada a adequar as mensalidades escolares às normas de reajuste, fixadas pelo Conselho Estadual de Educação, dada a natureza coletiva do interesse em jogo, afastando a tese de haver, no caso, uma tutela estatal de interesses privados ou usurpação das atribuições do advogado. A matéria está hoje pacificada sob a Súmula 643 do STF.

Para que o Ministério Público esteja legitimado requer-se a existência de uma situação ou condição de consumidor, de relação de consumo ou da presença de direitos coletivos, interesses sociais ou individuais indisponíveis ${ }^{18}$. Dado que o rol de competências (constitucionais) aplicase ao Ministério Público como um todo, a definição das atribuições de cada espécie ou ramo é dada ao juízo competente (justiça comum ou especializada, federal, estadual ou distrital).

De forma geral, as funções do Ministério Público podem ser divididas em típicas e atípicas. As funções típicas são a promoção da ação penal pública, da ação civil pública, da defesa da ordem jurídica, do regime democrático e dos interesses sociais e individuais indisponíveis, do zelo pelo efetivo respeito dos Poderes Públicos e dos serviços de relevância pública aos direitos assegurados na Constituição.

São atribuições cometidas ao Ministério Público de forma atípica, que ainda hoje são exercidas, de forma supletiva pela instituição: (i) o patrocínio do reclamante trabalhista onde não haja Justiça do Trabalho; (ii) a substituição processual das vítimas necessitadas nas ações ex delicto; e (iii) a ação de investigação de paternidade de filhos havidos fora do casamento. Quanto a estas atuações semelhantes às de defensoria, o STF tem entendido que, apenas enquanto não se implemente em cada estado da União o ofício da Defensoria Pública, tal como previsto no art. 134 da Constituição, persistirá a atribuição de assistência judiciária prestada pelo Ministério Público.

${ }_{18}$ STF, RE 195.056/PR, Min. Rel. Carlos Velloso, Tribunal Pleno. Julgamento em: 09/12/1999, 
Apesar das críticas aos ofícios atípicos do Ministério, é correto dizer que o interesse indisponível deve ser fiscalizado pelo Ministério Público, o que não significa que a instituição só oficie em defesa de interesses indisponíveis. Ou seja, se num processo judicial estiver em questão interesse indisponível, deverá haver a intervenção ministerial quer se trate de interesse individual indisponível ou social indisponível; por isso se diz que indisponibilidade é nota marcante ou predominante da atuação do Ministério Público.

Mas o MP não atua somente nos casos de indisponibilidade. Há relações entre os indivíduos que muitas vezes não são indisponíveis, mas, pela natureza ou abrangência, interessam, senão a toda a sociedade ou à comunidade como um todo, ao menos a um grupo tão expressivo que se pode tornar socialmente proveitosa sua atuação. Não raro o Ministério Público atua em defesa de interesses individuais homogêneos, interesses coletivos ou difusos, comungados por milhares ou até milhões de pessoas.

Quer atue em função típica ou atípica, em suas atividades o Ministério Público sempre age em busca de um interesse público, que ora está ligado a pessoas determinadas (e.g. zelo pelo interesse dos índios, incapazes, alimentandos, acidentados do trabalho, fundações, pessoas com deficiência); grupos de pessoas determinadas ou determináveis (e.g. a defesa judicial dos interesses das populações indígenas, consumidores, investidores coletivamente lesados); grupos indetermináveis de pessoas, como nos interesses difusos (e.g. defesa do meio ambiente ou o combate à propaganda enganosa); e toda a coletividade, de modo indeterminado (e.g. as ações penais, as questões atinentes ao estado das pessoas, a ação popular).

Em suma, desde que haja característica de indisponibilidade parcial ou absoluta de um interesse, ou desde que a defesa de qualquer interesse, disponível ou não, convenha à coletividade como um todo, aí será exigível a iniciativa ou a intervenção do Ministério Público junto ao Poder Judiciário.

\section{Imparcialidade e Defesa do Povo}

As leis cometem ao Ministério Público diversas atuações, respeitadas suas finalidades institucionais. Consequentemente, é correto dizer que o Ministério Público sempre tem um interesse a zelar. Contudo, como poderia ser um fiscal imparcial da lei, se tem um interesse a zelar? 
Ora, as expressões fiscal da lei e parte imparcial são lugares-comuns sem maior serventia técnica. Se o Ministério Público atua num processo, seja como autor, seja como interveniente, sob o aspecto técnico ele é parte. Por outro lado, tanto como órgão agente quanto como interveniente, ele sempre atua para fiscalizar o correto cumprimento da lei. Ele é parte, sim, porque é titular de ônus e faculdades na relação processual; e ele é interessado, sim, em defender aquele bem jurídico que a Constituição e leis puseram em suas mãos. O que importa é buscar a causa que trouxe o Ministério Público a um processo, para, a partir daí, compreender as finalidades protetivas de sua atuação.

$\mathrm{Na}$ Constituinte, por influência estrangeira (como o ombudsman escandinavo), chegou-se a cogitar da criação de um ouvidor ou de um defensor do povo em nosso país ${ }^{19}$. Entretanto, um Ministério Público forte e independente dispensa tal órgão à parte, que, mesmo nos países onde foi criado, tem funções apenas investigatórias. Nosso Ministério Público, além de seu poder investigatório, tem a função de levar às barras dos tribunais os responsáveis pelas violações.

\section{O Parecer do Ministério Público}

Para a proteção de direito líquido e certo é cabível a ação do mandado de segurança, quando este direito não for tutelado por habeas corpus ou habeas data, e sempre que o responsável pela ilegalidade ou abuso de poder for autoridade pública ou agente de pessoa jurídica no exercício de atribuições do Poder Público ${ }^{20}$.

A Lei 12.016/2009 revogou a Lei 1.533/1951, oportunidade em que passou a disciplinar o mandado de segurança individual e coletivo no plano infraconstitucional. Tal mandamento legal tem por escopo regulamentar e estabelecer os parâmetros para a utilização de um dos mais importantes remédios constitucionais colocado a disposição do cidadão.

Já tratamos neste texto sobre a função constitucional do órgão ministerial de fiscalizar a aplicação da lei. Somada a esta disposição, temos no texto infraconstitucional que será eivado de nulidade o

${ }_{19}$ PORTO, Pedro Rui da Fontoura. Ministério Público Brasileiro: História de Uma Luta Institucional. Associação do Ministério Público Brasileiro do Estado do Rio de Janeiro: Princípios Institucionais do Ministério Público, 2013. Disponível em: $<$ http://www.amperj.org.br/emails/MinisterioPublicobrasileiro.pdf $>$. Acesso em: $30 \mathrm{de}$ janeiro de 2017.

${ }^{20}$ Constituição da República Federativa do Brasil de 1988, Art. 5º, LXIX. 
processo nas situações em que o Ministério Público deixar de ser intimado para acompanhar o feito no qual deveria intervir ${ }^{21}$.

A redação atual da Lei do Mandado de Segurança (Lei no 12.016/09) manteve a exigência da abertura de vista para intervenção ministerial. Nos termos do seu art. 12, findo o prazo processual o juiz ouvirá o representante do Ministério Público, que opinará, dentro do prazo improrrogável de dez dias. Por fim, com ou sem o parecer do Ministério Público, os autos serão conclusos ao juiz para a decisão, a qual deverá ser necessariamente proferida em trinta dias.

Não existe qualquer espaço para juízo de valor do magistrado acerca da necessidade ou não da intervenção ministerial no feito. Ao magistrado cabe tão somente a abertura de vista ao membro ministerial, que por sua vez analisará o conteúdo do pedido e causa de pedir do mandado de segurança sob sua apreciação, para então exarar manifestação se ostenta interesse público, primário ou não, que justifique sua intervenção. Isso porque, muitas vezes, as questões em discussão no mandado de segurança restringem-se a disputas estritamente patrimoniais (geralmente questões de índole tributária). Tanto é que a Recomendação 16/2010 de autoria do próprio Conselho Nacional do Ministério Público, em seu art. 5으, apontou como desnecessária a intervenção ministerial meritória em determinadas demandas, como no caso do mandado de segurança. Tal recomendação assegura, porém, a abertura de vista ao MP em respeito ao princípio da independência funcional.

O juiz cumpre seu dever ao abrir vista ao Ministério Público, este cumpre o seu exarando ou não parecer após a abertura de vista. Ocorre que, contrariando o mandamento da Lei 12.016/09, art. 12, observa-se que em inúmeros casos os magistrados (principalmente em sede de primeiro grau) não têm aberto vista dos autos para oferecimento de parecer pelo Ministério Público como fiscal da lei, o que é causa de nulidade absoluta.

O fundamento para tanto jaz no fato de que em razão da já conhecida posição de determinado membro ministerial no sentido de ausência de interesse público primário em relação a pontual questão, o juízo a quo simplesmente suprime a abertura de vista e profere sentença, desde logo, em detrimento da lei. A supressão de vista ao órgão ministerial é uma afronta não só ao princípio constitucional da legalidade, mas também ao princípio da independência funcional.

Portanto, é imprescindível a abertura de vista ao Ministério Público antes da sentença em sede de mandado de segurança, porque a lei

${ }^{21}$ Código de Processo Civil, Lei no $13.105 / 2015$, Art. 279, § 1º

2 JOURNAL OF INSTITUTIONAL STUDIES 2 (2016) 
presumiu a existência de indício de interesse público nessa modalidade de demanda. Por outro lado, isto não significa que o parquet deva sempre se manifestar sobre o mérito da causa; pode não fazê-lo, se julgar que o assunto versado na lide não afeta interesse individual ou social indisponível. Mas apenas o órgão ministerial pode declarar se determinado assunto interessa ou não ao Ministério Público, sendo absolutamente defeso ao magistrado não remeter os autos ao órgão ministerial por julgar que determinado tema não lhe interessa.

\section{O Advogado Geral do Tribunal DE JUSTIÇA DA UNIÃo EUROPEIA}

\section{A Formação da União Europeia}

Há diversas teorias sobre a integração europeia, dentre estas, a Teoria Neofuncionalista começa na premissa de que, promovendo-se cooperação funcional entre os Estados, é possível impedi-los de travar disputas agressivas. A lógica por trás dessa teoria é prevenir a guerra não de um modo negativo, mas positivo, por meio de projetos de cooperação com metas definidas capazes de beneficiar o coletivo e levar a união à prosperidade econômica. A Teoria Neofuncionalista vê a integração como um processo baseado na repercussão de um setor técnico, inicialmente não controverso, em outros setores com maior possibilidade de impacto político, envolvendo a gradual redução de poder do governo nacional e a aumento na centralização da resolução de problemas politicamente sensíveis ${ }^{22}$.

Atualmente, a maior parte dos estudos sobre a integração europeia começa com o saldo final da Segunda Guerra Mundial e o desejo de paz duradoura na Europa. Após a destruição e ruína dos anos de guerra e o clima de nacionalismo que os precedeu, muitos esperavam por um novo modelo de cooperação política. Esse ponto importante da história da Integração Europeia moderna, no entanto, deve ser considerado dentro de um período temporal muito mais extenso, uma vez que ideias de união entre os Estados europeus já haviam sido articuladas muito antes do século $X X^{23}$.

${ }^{22}$ LODGE, Juliet. The European Community and the Challenge of the Future. $2^{\mathrm{a}}$ ed. Basingstone: Palgrave Macmillan, 1993 (Introduction), p. xix.

${ }^{23}$ CRAIG, Paul; BÚRCA, Gráinne de. EU Law: Text, Cases, and Materials. $4^{a}$ ed. Oxford: Oxford University Press, 2008, p. 4. 
A guerra resultou em crise para vários países da Europa nos setores econômico, político e social, a maioria destes países não tinha recursos suficientes para se reerguer de forma independente, o que inspirou o surgimento de alianças comerciais a fim de promover o fortalecimento econômico das nações envolvidas. O primeiro grupo a se unir com este objetivo ficou conhecido como Benelux, formado pela Bélgica, Luxemburgo e Holanda. O Benelux tinha como objetivo facilitar o comércio entre os três países a partir da aplicação de taxas comerciais reduzidas, menos burocracia e a criação de incentivos tributários e aduaneiros.

Em 1950 foi elaborado pelo Benelux o Plano Schuman, que criou um mercado comum entre os países e inicialmente a homogeneização da produção de aço e carvão em países como a Alemanha e a França. No ano seguinte, a partir do Tratado de Paris, surgiu a Comunidade Europeia do Carvão e do Aço (CECA) ${ }^{24}$, integrado pelos membros do Benelux mais França, Alemanha e Itália.

O Benelux e a CECA prosperaram e trouxeram os benefícios econômicos almejados pelas nações que os integravam. Assim, em 1957, com o Tratado de Roma, foi instaurada a Comunidade Econômica Europeia, ou Mercado Comum Europeu, formado pelos membros do Benelux e da CECA. O objetivo era facilitar a circulação de mercadorias entre os Estados membros e fazer frente à hegemonia americana e soviética que dominavam o cenário econômico mundial naquela época.

Finalmente, em 1992 foi assinado o Tratado de Maastricht que efetivou a criação da União Europeia, que é o resultado da integração e cooperação entre os países europeus, desde o período pós-guerra. $\mathrm{O}$ objetivo comum era fortalecer suas economias e ganhar destaque no cenário econômico mundial. Ao grupo, antes composto pelos membros do Benelux mais França, Itália e Alemanha uniram-se o Reino Unido, Grécia, Dinamarca, Irlanda, Portugal, Espanha, Áustria, Finlândia e Suécia. Estes quinze países deram início ao que hoje é o bloco econômico de maior relevância no cenário global.

Hoje, a União Europeia é composta por vinte e oito países membros, e, por meio do processo de expansão chamado de Alargamento da União Europeia, negociações de adesão estão em andamento em cinco países candidatos (Albânia, Antiga República Jugoslava da Macedônia, Montenegro, Sérvia e Turquia) e mais dois potenciais candidatos (Bósnia Herzegovina e Kosovo).

${ }^{24} \mathrm{O}$ tratado que estabeleceu a Comunidade Europeia do Carvão e do Aço foi adotado em 18 de abril de 1951 e expirou em julho de 2002. 
Assim, apesar dos dilemas atuais da União Europeia em razão, principalmente, do desequilíbrio econômico entre alguns Estados membros, a UE continua a se beneficiar das políticas de união, de compromisso e consenso que a ela deram origem.

\section{O Tribunal de Justiça da União Europeia}

No modelo atual, o Tribunal integra o ramo judiciário da Comunidade Europeia e tem a função primária de examinar a legalidade das medidas tomadas pelos Estados-Membros da União Europeia; é o órgão responsável por garantir a interpretação e a aplicação uniforme da legislação da UE25.

O Tribunal de Justiça da União Europeia foi estabelecido pela primeira vez como um tribunal sob o tratado que criou a Comunidade Europeia do Carvão e do Aço (CECA). Em 1957, os Estados membros do CECA assinaram o Tratado de Roma, e, além da Comunidade Econômica Europeia, foi também fundada a Comunidade Europeia da Energia Atômica (CEEA ou EURATOM) e atribuída competência ao Tribunal de Justiça da União Europeia para solucionar conflitos legais relacionados a esses grupos, que mais tarde uniram-se no que recebeu o nome de Comunidades Europeias ${ }^{26}$, o tribunal recebeu o nome de Tribunal de Justiça das Comunidades Europeias.

Com a criação da União Europeia sob o Tratado de Maastrich, foi introduzida a estrutura caracterizada pelos Três Pilares da União Europeia, que seriam: as Comunidades Europeias, a Política Externa de Segurança Comum e a Cooperação Policial e Judicial em Matéria Penal. Assim, além da cooperação econômica que já existia, os Estados membros expandiram essa relação de solidariedade para os campos das relações externas e do direito penal. Contudo, até então, ao Tribunal havia sido atribuída competência limitada aos dois primeiros pilares.

O tratado mais importante para a compreensão do funcionamento do Tribunal de Justiça da União Europeia nos dias de hoje é o Tratado

${ }^{25}$ SHANY, Yuval. Assessing the Effectiveness of International Courts. Oxford:

Oxford University Press, 2014, p. 277. Disponível em:

$<$ http://www.oxfordscholarship.com/view/10.1093/acprof:oso/9780199643295.001.0001/ acprof-9780199643295?rskey=Bfp8Hc\&result=3>. Acesso em: 30 de janeiro de 2017.

${ }_{26}$ Uniram-se sob o Tratado de Bruxelas, ou Tratado de Fusão, assinado em 17 de março de 1948 e expirou em 1ํ de maio de 199 com o Tratado de Amsterdam. Seus signatários originais foram "Os Seis" (Benelux mais Alemanha Ocidental, França e Itália). 
de Lisboa, que aditou o Tratado de Roma e o Tratado de Maastrich, unindo-os sob o nome de Tratado sobre o Funcionamento da União Europeia que entrou em vigor no ano de 2009. Além disso, instituiu o Estatuto do Tribunal de Justiça na União Europeia na forma do Protocolo no 3 do Tratado sobre o Funcionamento da União Europeia.

Dentre as grandes mudanças implementadas pelo Tratado de Lisboa, está a extinção da estrutura dos Três Pilares. Hoje, no seio da UE, as decisões são tomadas segundo um processo de direito comum denominado processo legislativo ordinário. Contudo, o método intergovernamental continua a ser aplicado à política externa e de segurança comum, o que alguns autores consideram um resquício do que foi o Terceiro Pilar ${ }^{27}$.

Outro ponto relevante, é que a partir deste momento, nos termos do art. 19 (1) do Tratado da União Europeia, o Tribunal de Justiça passou a compreender três jurisdições: o Tribunal de Justiça, o Tribunal Geral e os tribunais especializados, sendo que até o momento, o único desta jurisdição é o Tribunal da Função Pública Europeia.

Quanto às funções do Tribunal de Justiça, este se encarrega de garantir a aplicação uniforme da legislação civil, criminal e administrativa pelos tribunais de instâncias inferiores, e também tem o dever de construir um sistema normativo coerente, assegurando que a divisão de poderes seja respeitada e protegendo aos direitos individuais, assim como fazem os tribunais constitucionais nacionais. A literatura europeia tende mais a esta segunda comparação.

Essa, inclusive, é uma das premissas do livro escrito por Alicia Hinarejos sobre o controle judiciário na União Europeia. Hinarejos explica que a primeira função do Tribunal seria garantir o equilíbrio entre o poder central e o poder exercido pelo governo de cada Estado membro. Mas seguindo a mesma dinâmica que afetou todos os sistemas europeus de revisão constitucional, o Tribunal de Justiça da União Europeia lentamente se transformou não apenas em um mediador quanto ao limite desses poderes, mas também em um guardião de direitos constitucionais ${ }^{28}$.

Existe uma Carta Constitucional da União Europeia e o Tribunal de Justiça pode ser considerado o seu guardião e intérprete máximo, com o

${ }^{27}$ CRAIG, Paul; BÚRCA, Gráinne de. EU Law: Text, Cases and Materials. 5ª ed. Oxford: Oxford University Press, 2011, p. 27.

${ }^{28}$ HINAREJOS, Alicia. Judicial Control in the European Union: Reforming Jurisdiction in the Intergovernmental Pillars. New York, NY: Oxford University Press, 2009, p. 5. 
condão de declarar a inconstitucionalidade das leis, se necessário. Além disso, dados os elementos federais do sistema judiciário da União Europeia, a função do Tribunal melhor se assemelha à função dos tribunais de última instância dos sistemas federativos.

O Tribunal de Justiça da União Europeia foi criado como um tribunal supranacional, integrando o projeto da Comunidade Europeia. A criação deste tribunal em nível supranacional tem a mesma lógica que a criação de qualquer outro tribunal superior: indivíduos confiam a solução de controvérsias a terceiros imparciais, assim como a função de garantir a conformidade com regras preestabelecidas.

Consideremos primeiro a forma como o TJUE lida com a proteção aos direitos fundamentais como parte de sua competência. Inicialmente, o Tribunal resistiu às tentativas de ser transformado em um garantidor dos direitos fundamentais ${ }^{29}$. Finalmente, ficou provada a necessidade de colaboração com os poderes judiciários nacionais, assim o Tribunal de Justiça da União Europeia adaptou suas funções para se tornar justamente o que os tribunais constitucionais nacionais esperavam do órgão julgador europeu, ou seja, que fosse o modelo europeu de um tribunal constitucional. Não podemos esquecer que o sistema judiciário da Comunidade Europeia jaz no respeito que os tribunais nacionais estão dispostos a ter pelo Tribunal de Justiça, e este, em compensação, jaz na concepção destes do que é a função adequada a ser exercida pelo Tribunal de Justiça enquanto tribunal constitucional.

O que diferencia a União Europeia de outros grupos econômicos, em aspectos legais, são os efeitos que a legislação da União Europeia tem sobre o sistema legal de seus Estados membros. Esses efeitos legais são produto da própria legislação europeia, e não resultado da legislação nacional, e eles emergem em razão de determinados regulamentos da corte mais alta da União Europeia, o Tribunal de Justiça, e não em virtude dos Tratados. Tais efeitos legais do Direito Europeu são o que o torna significante e substancialmente diferente de como o Direito Internacional opera normalmente. A doutrina definiu tais efeitos como os princípios da supremacia e do efeito direto ${ }^{30}$.

O princípio da supremacia se deve à proclamação de que a lei da União Europeia é suprema quando há conflito normativo entre leis nacionais e também entre leis nacionais constitucionais. Essa é uma afirmação não só em teoria legal abstrata na tentativa de inserir o

${ }^{29}$ Cf. Caso 1/58, Stork vs. High Authority, 1959, ECR 17; e Caso 40/64, Scarlata and others vs. Commission EEC, 1965, ECR 279.

${ }^{30}$ CHALMERS, Damiam; TOMKINS, Adam. European Union Public Law: Texts and Materials. Cambridge: Cambridge University Press, 2007, p. 46 
Direito Europeu na hierarquia normativa, mas também na prática. A imposição existente é de que todos os tribunais inseridos na UE, incluindo os tribunais nacionais, devem aplicar e conferir efeito a legislação da UE, mesmo quando essa entrar em confronto com a legislação nacional constitucional. É importante notar que não são apenas os Tratados que fizeram do Tribunal de Justiça supremo sobre a legislação dos Estados-Membros, mas também a legislação complementar criada pelas instituições inseridas nos Tratados.

$\mathrm{O}$ efeito direto determina que as partes invoquem e confiem nas disposições da lei europeia em procedimentos legais perante tribunais nacionais. A aplicação ou não de legislação internacional, normalmente, depende da disposição no sistema legal de cada país, mas em 1963, o Tribunal de Justiça determinou, no que muitos doutrinadores europeus reconhecem como o julgamento mais relevante da história do Tribunal ${ }^{31}$, que a partir de então essa questão seria determinada pela própria legislação da União Europeia vinculando todos os Estados membros, independente da previsão de seus sistemas legais nacionais.

\section{Procedimentos do Tribunal de Justiça}

Os procedimentos perante o Tribunal de Justiça ocorrem em duas fases: escrita e oral ${ }^{32}$. A fase escrita normalmente é a mais importante.

${ }^{31} \mathrm{O}$ caso em questão é o 26/62, Van Gend en Loos vs. Nederlandse Administrative der Belasingen [1963] ECR 1. "Van Gend en Loos é indiscutivelmente o julgamento mais importante do Tribunal até a data. Tendo em vista a forma como afasta o Direito europeu do modelo convencional do Direito internacional, é radical e revolucionário." CHALMERS, Damiam; TOMKINS, Adam. European Union Public Law: Texts and Materials. Cambridge: Cambridge University Press, 2007, p. 47. O Caso 26/62 foi um marco no Tribunal de Justiça da União Europeia a partir do qual ficou estabelecido que as disposições do Tratado que estabeleceu a Comunidade Econômica Europeia tem a capacidade de criar direitos que podem ser invocados tanto por pessoa física quanto jurídica perante os tribunais dos Estados membros da Comunidade (princípio do efeito direito).

32 Estatuto do Tribunal de Justiça da União Europeia (2004). Versão consolidada do Protocolo ( $n^{\circ} 3$ ), conforme alterado pelo Regulamento (UE, Euratom) $n^{\circ} 741 / 2012$ do Parlamento Europeu e do Conselho, de 11 de agosto de 2012 (JO L 228, de 23 de agosto 2012, p. 1), pelo artigo $9^{\circ}$ do Ato relativo às condições de adesão à União Europeia, do Tratado sobre o Funcionamento da União Europeia e do Tratado que institui a Comunidade Europeia da Energia Atómica (JO L 112, de 24 de abril de 2012, p. 21) e 
$\mathrm{Na}$ fase escrita, todas as petições, declarações, defesas e todos os documentos relevantes são apresentados pelas partes e instituições cujas decisões estão sendo questionadas. Todas estas informações são reunidas e resumidas pelo juiz-relator e analisadas durante a sessão plenária do Tribunal que decide: (i) o número de juízes que irão tratar do processo e que será de três, cinco ou quinze, consoante à importância e a complexidade do assunto, sendo que a maior parte dos processos é entregue a cinco juízes, são raras as situações em que um processo é tratado por todo o Tribunal; (ii) a necessidade de uma audiência (fase oral) e das conclusões do advogado geral.

A fase oral, por sua vez, é breve e limitada. O juiz-relator prepara e apresenta seu relatório ao Tribunal, o que, assim como no Judiciário brasileiro, é um resumo do caso e dos argumentos apresentados pelas partes. Neste momento, os representantes das partes podem fazer suas sustentações orais ao Tribunal e por este serem questionados, de forma semelhante ao que vemos nos julgamentos das ações penais em segunda instância no Brasil. Quando o Tribunal entende que é necessário o parecer do advogado geral, o mesmo é emitido algumas semanas após a audiência. Essa tem sido considerada uma parte importante da fase oral, no sentido em que esclarece questões do caso que o Tribunal considere relevantes para sua solução. Por fim, os juízes deliberam e pronunciam o acórdão.

Em via de recurso, o Tribunal de Justiça, por ser colegiado, tem a função de reavaliar decisões do Tribunal Geral (onde as decisões são monocráticas), no caso de questionamento à matéria de direito, nas condições e limites previstos no Tratado sobre o Funcionamento da União Europeia ${ }^{33}$. Não obstante, Estados-Membros, instituições da União Europeia, e partes interessadas podem, em alguns casos, impugnar da sentença quando a audiência de instrução tiver sido suprimida e ficar comprovado que seus direitos foram prejudicados.

Existe também um mecanismo em que qualquer parte interessada em um caso pode requerer que o Tribunal interprete o acórdão quando houver dúvida. Podemos comparar com os embargos de declaração do direito brasileiro, que são cabíveis quando houver, na sentença ou acórdão, obscuridade, contradição ou omissão.

Uma parte interessada também pode requerer a revisão de acórdão ao Tribunal de Justiça caso se descubra fato suscetível de exercer

pelo Regulamento (UE, Euratom) 2015/2422 do Parlamento Europeu e do Conselho de 16 de dezembro de 2015 (JO L 341 de 24 de dezembro de 2015, p. 14). Art. 20.

${ }_{33}$ Tratado de Lisboa sobre o Funcionamento da União Europeia. Tratado da União Europeia. 13 dez. 2007. Art. 256.

2 JOURNAL OF INSTITUTIONAL STUDIES 2 (2016) 
influência decisiva e que, antes de proferido o acórdão, era desconhecido do Tribunal e da parte que requer a revisão. $\mathrm{O}$ prazo máximo é de dez anos a contar da data do acórdão ${ }^{34}$. Esse recurso se assemelha à Ação Rescisória no Processo Civil brasileiro, ação independente que tem por objetivo reformar uma decisão transitada em julgado há no máximo dois anos quando houver vício no julgamento ou falta de legitimidade do órgão julgador ${ }^{35}$.

\section{Os Juízes do Tribunal de Justiça da União Europeia}

Originalmente, o Tribunal de Justiça da União Europeia consistia de sete juizes, mas em 2001, em Nice, os Estados membros decidiram que não seria aceitável que o Tribunal tivesse menos juízes do que Estados membros e assim o Tratado foi aditado para incluir tal previsão ${ }^{36}$, regra que posteriormente foi reproduzida no Tratado Constitucional ${ }^{37}$. Assim, o número de juízes varia de acordo com o número total de EstadosMembros, totalizando vinte e oito juízes atualmente.

$\mathrm{O}$ art. 17 do Estatuto do Tribunal determina que este seja constituído por um número ímpar de juízes para que não haja empate nas decisões. Contudo, a partir da entrada da Croácia na UE, o Tribunal agora tem vinte e oito juízes. Na prática, isso não gera qualquer problema, uma vez que a Grande Sessão consiste de um número fixo de quinze juízes e quando, excepcionalmente, o Tribunal se reúne por completo, os juízes novatos não participam da sessão.

Enquanto, por um lado, qualquer aumento significativo na quantidade de Juízes poderia prejudicar a coerência da jurisprudência, podendo significar que a sessão do plenário do Tribunal ultrapassaria o limite invisível entre um tribunal colegiado e uma assembleia deliberativa; por outro, a presença no Tribunal de membros de todos os Estados é indubitavelmente favorável ao desenvolvimento harmonioso da jurisprudência da União, levando em conta conceitos considerados fundamentais nos vários Estados-Membros, assim aumentando a receptividade das sentenças proferidas pelo Tribunal. Pode-se também

\footnotetext{
${ }^{34}$ Estatuto do Tribunal de Justiça da União Europeia, Art. 44.

${ }_{35}$ As condições para cabimento da Ação Rescisória estão previstas no Art. 966 do Código de Processo Civil Brasileiro, Lei no 13.105/2015.

36 Tratado da União Europeia e do Tratado que institui a Comunidade Europeia com as alterações neles introduzidas pelo Tratado de Atenas de 16 de abril de 2003, Art. 221. 37 Tratado de Roma, que estabelece uma Constituição para a Europa, assinado em 29 de outubro de 2004, Art. I-29(2), e Art. I-26(5).
} 
dizer que a presença de um juiz de cada Estado-Membro contribui para a legitimidade do Tribunal ${ }^{38}$.

O objetivo não é que os juízes sejam vistos como representantes de cada Estado, ou que todos os juízes se envolvam em todos os casos. Inclusive, a legislação europeia proíbe que as partes requeiram a troca de juízes em razão da nacionalidade ${ }^{39}$. O objetivo final, na realidade, é que a jurisprudência do Tribunal receba influência do sistema legal de todos os seus Estados-Membros de forma homogênea. O que ajuda a reforçar a autoridade e legitimidade do Tribunal sobre os EstadosMembros.

Como em todos os tribunais, a função principal do juiz do Tribunal de Justiça é acompanhar as audiências e decidir sobre os casos. A eficiência na execução dessa tarefa depende de dois fatores: o número de juízes e seu método de trabalho. Os vinte e oito juízes são designados para uma ou mais sessões dentre as oito existentes, cada uma é formada por três ou cinco juízes. Devido ao princípio do colegiado, não há decisões monocráticas no Tribunal de Justiça, da forma que existe no Tribunal Geral e no Tribunal da Função Pública.

Quanto à hierarquia no Tribunal, dentre os vinte e oito Juízes, é eleito o Presidente do Tribunal de Justiça para um mandato de três anos com a possibilidade de ser reeleito. $O$ presidente fornece a pauta com $o$ horário das audiências do Tribunal e da Grande Sessão para procedimentos judiciários e administrativos. Também cabe ao presidente atribuir os casos para as sessões e apontar o juiz que será o relator do caso. Atualmente, o presidente do Tribunal é o belga Koen Lenaerts, eleito em outubro de $2015^{40}$.

\section{Advogados Gerais}

A advocacia geral é uma instituição única do Tribunal de Justiça da União Europeia, apesar de muito semelhante a outras instituições dos Estados-Membros. O Protocolo do Tribunal de Justiça anexo ao Tratado de Paris previa que dois advogados gerais assistiam o Tribunal Justiça.

${ }^{38}$ ARNULL, Anthony. The European Union and its Court of Justice. Nova York, NY: Oxford University Press, 2006, p. 7.

${ }^{39}$ Estatuto do Tribunal de Justiça da União Europeia, Art. 18.

${ }^{40}$ Tribunal de Justiça da União Europeia, Comunicado de Imprensa no 121/15.

Disponível em: $<$ http://curia.europa.eu/jcms/upload/docs/application/pdf/201510/cp150121en.pdf >. Acesso em: 22 de junho de 2016.

2 JOURNAL OF INSTITUTIONAL STUDIES 2 (2016) 
A Decisão 2013/336/UE do Conselho ${ }^{41}$ aumentou o número de advogados gerais do Tribunal de Justiça para onze, com efeitos a partir de 7 de outubro de 2015. Importa proceder a nomeações para o período compreendido entre 7 de outubro de 2015 e 6 de outubro de $2021^{42}$. Alguns países têm representação permanente no corpo de advogados gerais, são esses: França, Alemanha, Itália, Polônia, Espanha e Reino Unido; os demais vêm dos outros Estados-Membros em regime de revezamento ${ }^{43}$.

Os advogados gerais gozam do mesmo status social dos juízes do Tribunal, e por isso, naturalmente, devem apresentar os mesmos requisitos. Neste sentido, preveem os arts. 253 e 254 do Tratado sobre o Funcionamento da União Europeia, que como os juízes, os advogados gerais são nomeados de comum acordo, por seis anos, pelos governos dos Estados-Membros, após consulta ao comitê previsto em lei, que tem a função de dar parecer sobre a adequação dos candidatos ao exercício das funções de juiz ou de advogado geral do Tribunal de Justiça e do Tribunal Geral, antes de os Governos dos Estados-Membros procederem às nomeações ${ }^{44}$.

Ainda seguindo os mesmos requisitos dos juízes do Tribunal, os advogados gerais são escolhidos dentre personalidades que ofereçam todas as garantias de independência e reúnam as condições estabelecidas nos respectivos países para o exercício das mais altas funções jurisdicionais ou que sejam jurisconsultos de reconhecida competência ${ }^{45}$. Depois de um ou dois mandatos como advogado geral, a mesma pessoa pode se tornar juiz do Tribunal de Justiça da UE e viceversa. Há vários exemplos desse intercâmbio na prática.

O background profissional dos advogados gerais depende da tradição de cada país. A Alemanha, por exemplo, tem certa tradição de nomear professores das faculdades de direito estaduais. A atual advogada geral

${ }^{41}$ Tribunal de Justiça da União Europeia, Comunicado de Imprensa n 113/15.

Disponível em: $<$ http://curia.europa.eu/jcms/upload/docs/application/pdf/201510/cp150113pt.pdf>. Acesso em: 22 de junho de 2016.

${ }^{42}$ Conselho da União Europeia, Decisão dos Representantes dos Governos dos

Estados-Membros que nomeia um advogado-geral do Tribunal de Justiça, 15 de junho de 2015. Disponível em: $<$ http://data.consilium.europa.eu/doc/document/ST-8810-2015INIT/pt/pdf $>$. Acesso em: 23 de junho de 2016.

${ }^{43}$ LENAERTS, Koen; MASELIS, Ignace; GUTMAN, Katheleen. EU Procedural Law.

Oxford: Oxford University Press, 2014, p. 17.

${ }^{44}$ Tratado sobre o Funcionamento da União Europeia, Art. 255.

45 Tratado da União Europeia, Art. 19. 
alemã, Juliane Kokott, tem um extenso currículo acadêmico, com títulos da Universidade de Bonn, Washington D.C., Heidelberg e Harvard. Kokott foi professora nas universidades de Mannheim, Augsburg e Düsseldorf. Do ano de 2000 até sua entrada no Tribunal, liderou o Instituto de Direito Europeu da Universidade de St. Gallen, na Suíça, onde foi professora correspondente nas cadeiras de Direito Internacional Público e de Direito Comercial Internacional ${ }^{46}$. Em contrapartida, outros países preferem nomear juízes.

\subsection{Origem Histórica}

A ideia de se ter conselheiros para assistir os juízes surgiu durante a negociação do Tratado de Paris, que em 1951 criou a Comunidade Europeia do Carvão e do Aço, a criação do cargo de advogado geral foi proposta pela delegação francesa à semelhança do seu commissaire $d u$ government, cargo assim nomeado em 1849. Em 1956, durante as negociações do Tratado de Roma, documento fundador da Comunidade Europeia, os Estados membros optaram por manter a figura do advogado geral no sistema legal do bloco que, a partir do Tratado de Lisboa, passou a ser chamado de União Europeia.

$\mathrm{O}$ primeiro a assumir o cargo foi Maurice Lagrange, membro da delegação que propôs o cargo e considerado seu criador. Antes de ser advogado geral do Tribunal, Lagrange foi commissaire du government no Conseil d'Etat da França. O commissaire du governement é um membro do tribunal de justiça francês que estuda os autos do processo e produz um parecer aconselhando como, em sua opinião, o caso deve ser julgado, tendo por base a legislação, a jurisprudência e as políticas do tribunal. Em tribunais administrativos de instâncias inferiores, membros do tribunal exercem as funções de commissaire du governement ad hoc. Já na instância do Conseil d'Etat, um determinado número de juízes ocupa esta função por alguns anos. Assim como no caso dos advogados gerais, os seus pareceres, apesar de influentes, não vinculam o tribunal ${ }^{47}$.

Desde o começo, Lagrange usou do direito comparado e da literatura jurídica internacional para determinar quais princípios e leis deveriam ser incorporados à base legal da Comunidade Europeia. Nesse sentido,

${ }^{46}$ Cf. Curriculum Vitae disponível em:

$<$ http://www.julianekokott.de/index.php/en/curriculum-vitae $>$. Acesso em: $04 \mathrm{de}$ outubro de 2016.

${ }^{47}$ BERMANN, George; PICARD, Etienne (eds.). Introduction to French Law. Alphen aan den Rijn: Kluwer Law International, 2008, p. 100. 
os pareceres usavam de analogias, inspirando-se em casos semelhantes que tivessem ocorrido em Estados-Membros e, quando relevante, também lançava mão do direito internacional. Ele examinava as leis dos Estados-Membros que fossem pertinentes para a solução do caso em questão e estudava as decisões proferidas pelos tribunais nacionais em casos de conteúdo semelhante, a fim de extrair princípios em comum que pudessem ser aplicados, de forma análoga, à interpretação dos Tratados ${ }^{48}$.

\subsection{Funções}

A tomada de decisões no Tribunal de Justiça é assistida pelo corpo de advogados gerais. $O$ advogado geral é um membro pleno do Tribunal de Justiça e participa da fase oral da audiência. A função mais importante do advogado geral é produzir um parecer a ser apresentado antes da sentença. Os advogados gerais não precisam estar envolvidos em todos os casos, o Estatuto do Tribunal prevê em seu art. 20 que, quando considerar que não se suscita nova questão de direito, o Tribunal pode, ouvido o advogado geral, decidir que a causa seja julgada sem parecer do advogado geral.

A terminologia adequada para a manifestação, ou parecer, do advogado geral é conclusões do advogado geral. Este documento deve demonstrar a visão de seu autor acerca da legislação e recomendar como o caso deve ser julgado. $\mathrm{O}$ Tribunal não está vinculado a este parecer, mas é fortemente influenciado por esta opinião do advogado geral. $\mathrm{O}$ objetivo do parecer é apresentar um conselho imparcial e independente. Na prática, é uma visão compreensiva e razoável da legislação aplicável ao caso. Frequentemente, apresentará comentários e explicações sobre alguma jurisprudência do Tribunal de Justiça que seja de difícil interpretação.

Contudo, o papel do advogado geral não se esgota na assistência que ele presta ao Tribunal na resolução de um litígio específico. Ele pode comentar sobre questões incidentais do processo cuja análise não seja estritamente necessária para o julgamento do mérito. Tem, portanto,

${ }^{48}$ GREAVES, Rosa. The first Advocate General, Maurice Lagrange. In: BURROWS, Noreen; GREAVES, Rosa: The Advocate General and EC Law. Oxford: Oxford University Press, 2009. Disponível em:

<http://www.oxfordscholarship.com/view/10.1093/acprof:oso/9780199299003.001.0001/ acprof-9780199299003-chapter-4>. Acesso em: 23 de junho de 2016. 
uma função mais ampla, faz uma análise crítica da jurisprudência, identificando tendências, apontando possíveis incoerências e delimitando possíveis desenvolvimentos futuros. A respeito disso, a independência do advogado geral em relação aos juízes é de extrema importância. Parte dessa função ampla é expressar suas opiniões, criticando, quando achar necessário, princípios estabelecidos em casos anteriores, mesmo em circunstâncias em que seja extremamente improvável que o Tribunal acolha sua opinião.

Parte da função do advogado geral que vai além do caso concreto é expressar suas opiniões sobre a evolução do direito europeu, inclusive criticar princípios estabelecidos em casos anteriores. Assim, não é um defensor do direito das partes, na realidade, pode-se dizer que o advogado geral é um protagonista objetivo no processo da aplicação e do desenvolvimento do Direito Europeu. O seu objetivo é garantir a consistência deste desenvolvimento e também solucionar o caso concreto de uma forma justa.

\subsection{Conclusões do Advogado Geral}

$\mathrm{O}$ art. 222 do Tratado sobre o Funcionamento da União Europeia prevê que o Tribunal de Justiça seja assistido pelos advogados gerais aos quais cabe apresentar publicamente, com toda a imparcialidade e independência, conclusões fundamentadas sobre as causas que, nos termos do Estatuto do Tribunal de Justiça da União Europeia, requeiram a sua intervenção.

Dentre a totalidade dos advogados gerais, os membros do tribunal devem designar o Primeiro Advogado Geral, conforme preveem as Regras de Procedimento do Tribunal de Justiça da União Europeia, que exercerá a função pelo período de um ano ${ }^{49}$. Desde 1979 os casos não são mais atribuídos pelo Presidente do Tribunal, mas sim pelo Primeiro Advogado Geral, que apesar de ter esta competência, é apenas um primus inter pares, não é hierarquicamente superior aos demais advogados gerais.

As decisões do Tribunal de Justiça devem ser motivadas ${ }^{50}$. Tendo em vista que o Tratado sobre o Funcionamento da União Europeia coloca a tarefa de produzir fundamentação legal como o cerne das funções do advogado geral, não é surpresa alguma que o Tratado faça as mesmas

${ }^{49}$ Regulamentos Internos e de Processo: Regulamento de Processo do Tribunal de Justiça, 2012, Art. 14.

${ }^{50}$ Estatuto do Tribunal de Justiça da União Europeia, Art. 36. 
exigências para a seleção dos advogados gerais que para os juízes do Tribunal.

A partir do momento que um caso é atribuído a um advogado geral, este deve produzir um parecer aconselhando o Tribunal sobre como, em sua visão, o caso deve ser solucionado. Como previamente mencionado, o parecer não vincula o Tribunal e tampouco o advogado geral delibera sobre o caso, quem o faz são os juízes em colegiado e sob sigilo ${ }^{51}$. Entretanto, desde 1994, o relatório da audiência, que é preparado pelo juiz relator e resume os argumentos apresentados pelas partes durante a fase escrita, não é mais publicado nos boletins oficiais do Tribunal. Desde então, alguns advogados gerais passaram a ver como sua responsabilidade fornecer um relatório mais completo, que aborda em detalhe as questões de fato e de direito que envolvem o caso. Assim, as conclusões têm um alcance que excede o julgamento: são publicadas na Coletânea da Jurisprudência do Tribunal de Justiça da União Europeia e também no sítio eletrônico do Tribunal no mesmo dia em que são apresentadas ${ }^{52}$.

Os pareceres dos advogados gerais são, na maioria das vezes, de melhor compreensão que os julgamentos do Tribunal e assim esclarecem julgamentos que, por vezes, são obscuros e de difícil compreensão ${ }^{53}$. Uma vez que são o produto de uma única pessoa, apresentam uma clareza e objetividade que os acórdãos do Tribunal nem sempre têm, e por isso são de grande valor para os estudiosos do Direito Europeu, sejam esses acadêmicos, advogados ou simplesmente membros do público geral.

O parecer pode conter uma análise comparativa das leis dos EstadosMembros a fim de extrair um princípio comum ao Direito Europeu. Adicionalmente, espera-se que o parecer apresente uma análise completa da jurisprudência e da legislação relevantes, de forma que auxilie o Tribunal a chegar a uma decisão. É natural que o parecer reflita

${ }^{51}$ TRIDIMAS, Takis. The Role of the Advocate General in the Development of

Community Law: Some Reflections. Common Market Law Review, Vol. 34. 6, 1997, p. 1349-1387. Disponível em:

$<$ https://www.kluwerlawonline.com/abstract.php?area=Journals\&id=157630 $>$. Acesso em: 04 de outubro de 2016.

52 Tribunal de Justiça da União Europeia: CURIA (Apresentação da Coletânea).

Disponível em: $<$ http://curia.europa.eu/jcms/jcms/P 106308/pt/> . Acesso em: $04 \mathrm{de}$ outubro de 2016.

53 CRAIG, Paul; BÚRCA, Gráinne de. EC Law: Text, Cases, and Materials. Oxford: Clarendon Press, 1996, p. 94. 
a origem do advogado que o escreveu, ou seja, advogados que vêm de países como a Inglaterra, cujo sistema legal é o common law, tendem a apresentar pareceres ricos em jurisprudência. Pareceres de advogados gerais que originam de países que usam do sistema romano, ou civil law, como a Alemanha, normalmente têm um valor acadêmico mais forte, com mais citações a doutrina do que o primeiro. $\mathrm{O}$ Tribunal tem sido o recipiente da mescla dos diversos sistemas legais dos seus EstadosMembros. Atualmente a dicotomia estilística civil law versus common law está cada dia menos perceptível ${ }^{54}$.

\subsection{Impacto Socioeconômico das Conclusões do Advogado Geral}

Além da questão já abordada quanto ao valor acadêmico das conclusões e sua função social de prestar esclarecimentos à população europeia e quem mais se interesse pelos julgamentos da corte, esses pareceres podem ter uma influência ainda maior. Para entender os possíveis impactos, vejamos o caso do Outright Monetary Transactions (Transações Monetárias Definitivas em português e OMT na sigla em inglês), em que a publicação das conclusões do então advogado geral Pedro Cruz Villalón ${ }^{55}$, afetaram de forma significativa os mercados europeus.

O OMT é um programa de compra de dívida pública anunciado pelo Banco Central Europeu (BCE) em 2012 para ajudar os Estados-Membros em dificuldades fiscais. O programa, que até hoje não entrou em prática, tinha como objetivo estabilizar a zona do Euro em razão das crises na Irlanda, Espanha, Portugal e Grécia. A sua legalidade, entretanto, foi questionada pela corte constitucional da Alemanha. A crítica tinha como

54 TRIDIMAS, Takis. The Role of the Advocate General in the Development of Community Law: Some Reflections. Common Market Law Review, Vol. 34. 6, 1997, p. 1349-1387. Disponível em:

<https://www.kluwerlawonline.com/abstract.php?area=Journals\&id=157630>. Acesso em: 04 de outubro de 2016, p. 1349-1387.

55 Pedro Cruz Villalón foi advogado geral do TJUE de novembro 2009 a outubro 2015, quando foi substituído por Manuel Campos Sánchez-Bordona. Cf. Tribunal de Justiça da União Europeia, Comunicado de Imprensa ${ }^{\circ}$ 113/15: Renovação parcial do Tribunal de Justiça e entrada em funções de um novo Membro no Tribunal Geral da União Europeia. Disponível em: <http://curia.europa.eu/jcms/upload/docs/application/pdf/2015-10/cp150113pt.pdf>. Acesso em: 22 de junho de 2016. 
base o Tratado de Maastricht, que estabeleceu a união monetária e que proíbe que o BCE financie os Estados-Membros. Como as cortes constitucionais dos Estados-Membros não têm competência para julgar sobre uma violação do direito europeu, o tribunal alemão interrompeu o processo do OMT por meio de um instrumento jurídico chamado Verfassungsbeschwerde (um instrumento análogo à ação direta de inconstitucionalidade brasileira), e remeteu o caso ao Tribunal de Justiça da União Europeia.

Qualquer decisão do TJUE teria grande impacto na valorização da moeda única europeia e também nas moedas de fuga mais usadas, o Franco Suíço e a Coroa Sueca. Durante a crise do Euro, o Franco Suíço já havia valorizado muito, devido à alta procura daqueles que recorrem à moeda pela sua estabilidade em meio à crise. Mas esta prática pode ser prejudicial à economia suíça, que depende muito do mercado externo. A alta da sua moeda nacional torna seus produtos e serviços menos competitivos. Para enfrentar este problema, o Banco Nacional Suíço (BNS) publicou em 2010 a declaração de que compraria Euros para assegurar que o valor máximo do Franco Suíço não excedesse CHF 1,20 para EUR 1,00. Essa promessa custou caro, só no ano de 2014, o BNS perdeu cinco bilhões de Francos Suíços, o equivalente a quase dezessete bilhões de Reais ${ }^{56}$.

A eminente desvalorização do Euro chegou a uma dimensão que tornou a promessa do BNS uma missão impossível. O Franco Suíço estava com alta de $20 \%$ o que gerou crise no comércio das fronteiras da Suiça, no turismo e começava a afetar a indústria do país ${ }^{57}$. Finalmente, em janeiro de 2015 foi publicada a opinião favorável do advogado geral do TJUE ao OMT. Apesar do parecer não ter valor de sentença, sua influência é tão ampla que, apenas um dia após Cruz Villalón rejeitar, de forma bem clara e completa, as preocupações do tribunal constitucional alemão, o Banco Nacional da Suíça retirou sua promessa e suspendeu a compra desenfreada de Euros. O BCE, por sua vez,

${ }^{56}$ SESTER, Peter. The Opinion of the Advocate General on the Announced BondBuying Program of the ECB. CapLaw: Swiss Capital Markets Law, No. 34, 2015.

Disponível em: $<$ http://www.caplaw.ch/2015/the-opinion-of-the-advocate-general-onthe-announced-bond-buying-program-of-the-ecb/>. Acesso em: 04 de outubro de 2016. 57 SESTER, Peter. The Opinion of the Advocate General on the Announced BondBuying Program of the ECB. CapLaw: Swiss Capital Markets Law, No. 34, 2015. Disponível em: $<$ http://www.caplaw.ch/2015/the-opinion-of-the-advocate-general-onthe-announced-bond-buying-program-of-the-ecb/>. Acesso em: 04 de outubro de 2016. 
voltou a se sentir confortável para dar início à compra de títulos de dívida pública ${ }^{58}$.

Este caso mostra de uma forma impressionante como apenas as conclusões do advogado geral são suficientes para que o mercado financeiro europeu e até para que o banco central de um país terceiro reajam de forma drástica. Finalmente, o TJUE publicou sua decisão sobre o caso em julho de 2015, também favorável à legalidade da OMT, o que foi apenas um detalhe e não teve o mesmo efeito nos mercados, afinal, todas as consequências possíveis decorrentes do caso já haviam acontecido. Ocorreu que a decisão breve dos juízes, de menos de trinta páginas, apenas confirmou as detalhadas conclusões do advogado geral, documento que excede cem páginas, comprovando a relevância do cargo.

\subsection{Efeitos Práticos das Conclusões do Advogado Geral sobre Julgamentos do TJUE}

O Tribunal de Justiça da União Europeia julga seus casos a favor de um autor ou réu, podendo optar por acompanhar as conclusões dos advogados gerais ou não; a frequência com a qual isso ocorre é uma questão recorrente e até mesmo envolvida por certo mistério. $\mathrm{O}$ Tribunal não publica estatísticas oficiais, assim, nos resta recorrer à mídia especializada para estimativas. O mais comum é que se encontrem referências à razão de $80 \%$ dos casos. Contudo, em 2010, o site de notícias jurídicas Out-Law, fundado pelo escritório inglês Pinsent Masons LLP, publicou um artigo em que desafia essa percentagem, que, segundo a publicação, se tornou mais hábito do que fato ${ }^{59}$.

De acordo com o artigo supracitado, este número é usado há anos sem qualquer tipo de fonte oficial. Quando se trata do TJUE, qualquer tipo de suposição é arriscada, tendo em vista que as decisões são demoradas, podendo levar anos das conclusões do advogado geral até a

${ }^{58}$ ANÍBAL, Sérgio. Tribunal europeu deixa BCE mais à vontade para começar a comprar dívida pública. Público, Portugal, 14 jan. 2015. Disponível em:

$<$ https://www.publico.pt/economia/noticia/tribunal-europeu-deixa-bce-mais-avontade-para-comecar-a-comprar-divida-publica-1682164>. Acesso em: 01 de julho de 2016.

${ }^{59}$ ROBERTSON, Struan. How often does the ECJ follow Advocates General? Or should that be CJEU? Out-Law, Inglaterra, 18 out. 2010. Disponível em: $<$ http://www.outlaw.com/page-11458>. Acesso em: 01 de julho de 2016. 
decisão final, e também considerando que as conclusões podem ser parcialmente acolhidas.

A situação fica ainda mais complicada em razão do Tratado de Nice, que entrou em vigência em 2003. Desde então os advogados gerais não opinam em todos os casos e, agora, como previamente mencionado, apenas se manifestam quando há matéria nova de direito. Assim, as conclusões ficam reservadas aos casos mais complexos, que são justamente o tipo que tende a gerar mais discordância entre dois especialistas, o que torna o cálculo de $80 \%$ ainda mais improvável, sugerindo que esse número, na verdade, seja muito menor ${ }^{60}$.

\section{COMPARAÇÕES}

\section{Diferentes Conceitos de Estado Democrático}

Relembrando o que falamos anteriormente a respeito da origem do Ministério Público ser comumente atribuída aos procuradores do rei do direito francês arcaico, com a Revolução Francesa e a Era Napoleônica tendo influenciado fortemente a instituição como ela é hoje. O modelo francês inspirou o de outras nações, sendo também de grande influência no Brasil. Como visto anteriormente, um ponto fundamental que permitiu essa influência é a visão dos povos francês e brasileiro sobre o Estado, que em ambos os casos favorecem claramente a emergência e o poder de uma instituição que toma conta do interesse do Estado.

Quando comparamos Brasil e França com um país como a Suíça e a visão de seu povo sobre o Estado, notamos que este não permitiria uma instituição como o Ministério Público francês ou brasileiro. Diferente desses povos, os suíços são caracterizados por um grande ceticismo com relação ao Estado $^{61}$. A Constituição Suíça não prevê grande intervencionismo estatal, instituindo um Estado que estimula a

${ }^{60}$ ROBERTSON, Struan. How often does the ECJ follow Advocates General? Or should that be CJEU? Out-Law, Inglaterra, 18 out. 2010. Disponível em: $<$ http://www.outlaw.com/page-11458>. Acesso em: 01 de julho de 2016.

${ }^{61} \mathrm{CHURCH}$, Clive; DARDANELLI, Paolo. Twelve Key Points about Swiss Politics and Democracy, 2008. Disponível em: <

<https://pt.scribd.com/document/311856858/Twelve-Key-Points $>$. Acesso em: 07 de julho de 2016.

2 JOURNAL OF INSTITUTIONAL STUDIES 2 (2016) 
iniciativa privada, sem deixar de garantir condições de subsistência básica à população ${ }^{62}$.

Podemos demonstrar essa cultura por meio dos bancos nacionais de desenvolvimento, presentes em países como a França ${ }^{63}$, Alemanha e Brasil $^{64}$. Esses bancos são controlados pelo Estado, servem para fomentar a economia nacional e até como forma dos governos intervirem e direcionarem a economia, quando necessário. Na Suíça, país marcado pela democracia direta e grande envolvimento popular na política econômica do país ${ }^{65}$, esse distanciamento no controle de uma instituição de desenvolvimento em nível nacional seria impensável; no modelo suíço existem os bancos cantonais, que correspondem a 30\% de toda a atividade bancária do país, cujos objetivos estão centralizados no fomento da economia do cantão em que se inserem ${ }^{66}$. Esse sistema, obviamente, viabiliza o controle da própria população local sobre os recursos administrados pelos bancos, e, assim, o controle deixa de ser outorgado a uma instituição fiscalizadora em âmbito nacional.

A constituição suíça não estabelece uma corte constitucional nem um Ministério Publico no sentido francês ou brasileiro. É responsabilidade dos próprios cidadãos, através de ação civil e de outros meios característicos da democracia direita, exercer o controle político e fiscalizar as leis. Um exemplo disso é a sujeição de decisões políticas que

${ }^{62}$ Constituição Federal da Confederação Suíça de 18 de Abril de 1999, Art. 41.

Disponível em: $<\underline{\text { https://www.admin.ch/opc/en/classified- }}$ compilation/19995395/201601010000/101.pdf > . Acesso em: 04 de outubro de 2016.

${ }^{63}$ Agence Française de Développement (ou Agência Francesa de Desenvolvimento), criada em 1941, age em nome do governo francês para promover o desenvolvimento financeiro de acordo com as políticas de assistência internacional da França. Cf. $<$ http://www.afd.fr/lang/en/home/AFD/presentation-afd $>$. Acesso em: 04 de outubro de 2016.

${ }^{64}$ FARIA, Luis Gustavo Joaquim de. A atuação do BNDES no Brasil e do KFW na Alemanha: uma comparação. Disponível em: $<$ http://s3.amazonaws.com/acadex.articles/Articles/56e5d94a8e0106b55db67706fileIdentified.pdf $>$. Acesso em: 04 de outubro de 2016.

${ }^{65}$ FELD, Lars; KIRCHGÄSSNER, Gebhard. Direct Democracy, Political Culture, and the Outcome of Economic Policy: a Report on The Swiss Experience. European Journal of Political Economy, Vol. 16, 2, 2000, p. 287-306.

${ }^{66}$ DIETRICH, Andreas; WANZENRIED, Gabrielle. What determines the profitability of commercial banks? New evidence from Switzerland, 2009, p. 2-39. Disponível em: $<$ http://citeseerx.ist.psu.edu/viewdoc/download?doi=10.1.1.498.7051\&rep=rep1\&type= pdf $>$. Acesso em: 04 de outubro de 2016.

2 JOURNAL OF INSTITUTIONAL STUDIES 2 (2016) 
envolvam gastos públicos a um referendo ${ }^{67}$. Em um ambiente como este não há espaço para um Ministério Público inserido no direito civil e administrativo, assim, os procuradores gerais da Suíça (Bundesanwaltschft) se restringem ao direito penal, agindo no âmbito de crimes cometidos diretamente contra a Confederação e seus interesses (e.g. crime organizado, lavagem de dinheiro e corrupção) ${ }^{68}$.

A figura dos advogados gerais, que se aproxima dos procuradores do Ministério Público brasileiro, surgiu durante as negociações de tratados fundamentais para a União Europeia, sugerido justamente pela delegação francesa, que fez a proposta de integrar este cargo de seu ordenamento jurídico ao sistema europeu. Contudo, a função do procurador do Estado francês não poderia ser traduzida literalmente para o direito europeu, precisava ser adaptado às necessidades da União, que em muito divergem daquelas de um Estado.

$\mathrm{O}$ direito da União Europeia tem uma importância extraordinária para a sua própria existência, porque somente este direito garante que o futuro e o funcionamento da UE se tornem independente da política do dia-a-dia dos Estados-Membros. Dessa independência surge a dificuldade de fiscalização da aplicação efetiva das leis europeias por parte da população dos Estados-Membros, e é a partir disso que surge a necessidade de uma instituição fiscalizadora que, pelo menos em alguns aspectos, seja comparável ao Ministério Público do Brasil. Assim, na União Europeia há dois órgãos que exercem as funções do Ministério Público brasileiro: a Comissão Europeia e os advogados gerais do TJUE. A Comissão pode tomar a iniciativa e processar Estados-Membros ou órgãos da União Europeia, os advogados gerais não podem tomar esta iniciativa, mas opinam nos casos dos processos que chegam ao Tribunal de Justiça da União Europeia em Luxemburgo.

${ }^{67}$ FELD, Lars; MATSUSAKA, John. Budget Referendums and Government Spendind: Evidende from Swiss Cantons. Journal of Public Economics, Vol. 87, 12, 2003, p. 27032724. Disponível em:

$<$ http://citeseerx.ist.psu.edu/viewdoc/download?doi=10.1.1.130.325\&rep=rep1\&type $=$ p df $>$. Acesso em: 04 de outubro de 2016.

${ }^{68}$ GILLIÉRON, Gwaladys. Public Prosecutors in the United States and Europe: A Comparative Analysis with Special Focus on Switzerland, France and Germany. Monografia (Graduação em Direito). Faculdade de Direito da Universidade de Zurique, Zurique, 2013, p. 171. 


\section{O Tribunal de Justiça da União Europeia e os Tribunais Superiores do Brasil}

A melhor forma entender o TJUE é a partir da comparação que pode ser feita com a estrutura judiciária do Brasil. A União Europeia compreende vinte e oito países, cada um com o seu próprio sistema normativo, tradição e cultura jurídica. Para regulamentar a forma como estes países se relacionam no contexto da União, foi criado o TJUE. O doutrinador americano Martin Shapiro escreveu sobre o que ele chamou de Logic of Courts (Lógica dos Tribunais, em tradução literal). Nesta lógica, indivíduos - em nosso contexto, Estados membros - confiam a solução de controvérsias a terceiros imparciais, que asseguram a legalidade da resolução por meio de regras preestabelecidas ${ }^{69}$. Essa ideia se aplica tanto às nossas cortes, como ao tribunal europeu enquanto órgão julgador em nível supranacional.

As funções do TJUE relevantes para a nossa comparação são duas: garantir a aplicação e fiscalização dos tratados, que são o equivalente a uma constituição, no âmbito da União Europeia; e assegurar a interpretação uniforme das leis europeias em toda a União. Lei, neste contexto, significa o conjunto das diretivas e regulações da UE, incluindo as normas estabelecidas nos tratados.

No Brasil, essas funções são exercidas pelos tribunais superiores. Sendo o Superior Tribunal Federal o guardião máximo da Constituição brasileira; e o Superior Tribunal de Justiça a corte responsável por garantir que a lei federal seja aplicada da mesma forma nos tribunais de instâncias inferiores em todos os estados da federação.

\section{O Advogado Geral e o Procurador do Ministério Público}

A primeira comparação pode ser feita em torno da estabilidade da previsão legal que instituiu cada cargo. $\mathrm{O}$ advogado geral foi inserido no direito europeu por meio de tratados, e apesar de ser uma instituição importante para a estrutura do sistema judiciário, um novo tratado pode surgir desconstruindo o cargo. Enquanto o Ministério Público existirá, no mínimo, por quanto tempo a Constituição de 1988 estiver em vigor, tendo em vista que é, nas palavras do texto constitucional, uma "instituição permanente", se estabelece com cláusula pétrea, ou seja, faz parte do núcleo inalterável da Constituição Federal.

${ }^{69}$ SHAPIRO, Martin. Courts, a comparative and political analysis. Chicago:

University of Chicago Press, 1986, p. 36.

2 JOURNAL OF INSTITUTIONAL STUDIES 2 (2016) 
Os tratados europeus e a lei brasileira estabelecem também diferentes formas de admissão na carreira. Como vimos, os advogados gerais são apontados pelos governos dos Estados-membros e então sujeitos à aprovação de um comitê especializado. Em contrapartida, os membros do Ministério Público devem ser aprovados nos concursos de provas e títulos, além do requisito, um pouco mais recente, de que exerçam atividade jurídica por três anos depois de formados para que estejam habilitados para o concurso ${ }^{70}$. Esse último requisito impõe, de forma objetiva, que o candidato tenha um mínimo de experiência prática para exercer as funções. $\mathrm{Na} U E$, os advogados gerais são apontados entre personalidades já reconhecidas no meio jurídico, seja por suas contribuições acadêmicas, ou pelo exercício de cargo nos tribunais nacionais. Assim, geralmente, já chegaram ao topo da carreira quando são nomeados.

Uma vez admitidos, os membros do MP passam pelo período probatório e então gozam da garantia à vitaliciedade. $\mathrm{Na}$ União Europeia, o advogado geral exerce suas funções por seis anos, podendo ser apontado novamente para o cargo. Apesar dos cargos não compartilharem da mesma garantia quanto à estabilidade de carreira, o princípio mais importante sobre o exercício das funções do advogado geral recai também sobre seu semelhante do direito brasileiro: a independência. Para garantir que o advogado geral exerça suas funções de resguardo do direito europeu sem qualquer influência, esse tem total independência, inclusive em relação aos juízes do Tribunal. $\mathrm{O}$ mesmo se aplica ao MP, que como vimos, é independente em relação à instituição como um todo e a cada membro individualmente.

Para garantir a independência, a imparcialidade e a dedicação total à carreira, a lei europeia proíbe que os advogados gerais e juízes exerçam qualquer atividade profissional, exceto pelo magistério. Também no Brasil é possível combinar uma posição no Ministério Público com uma cátedra em uma universidade ou cursos preparatórios para concursos.

Outra semelhança que se pode apontar entre os advogados gerais e os membros do Ministério Público brasileiro é a imparcialidade indispensável de ambos, mesmo quando o segundo é parte no processo. Na qualidade de parte, o Ministério Público executa tarefas de grande alcance social e político. À sua tradicional função de titular da ação penal pública, alia-se à missão de salvaguarda dos direitos difusos e coletivos. Parte da missão do MP é resguardar esses direitos de uma forma proativa. O maior contraste, judicial e extrajudicialmente, é que o advogado geral não tem a função de defender os direitos fundamentais

${ }^{70}$ Alteração trazida pela Emenda Constitucional no 45 de 30 de dezembro de 2004.

2 JOURNAL OF INSTITUTIONAL STUDIES 2 (2016) 
difusos e coletivos, pois estes não são reconhecidos por muitos países da UE, nem pelo próprio direito europeu.

Por fim, da mesma forma que o advogado geral resguarda a boa aplicação do direito europeu, o Ministério Público, como custos legis, desempenha a atividade fiscalizadora pertinente à correta aplicação da lei, por isso é conhecido como o "fiscal da lei". As duas instituições garantem a alta qualidade técnica e hermenêutica do sistema judiciário. Ademais, ambos têm a função de garantir equilíbrio frente ao poder dos juízes, garantindo o bom funcionamento do sistema de freios e contrapesos em sua jurisdição.

\section{CONCLUSÕES}

A comparação entre o Ministério Público do direito brasileiro e o advogado geral do direito europeu revelou semelhanças e contrastes entre essas instituições. Ambas têm suas raízes no direito francês e um modo de operação similar, qual seja, a elaboração de pareceres nãovinculantes para as cortes judiciais. Entretanto, assumem o Ministério Público e o advogado geral funções bastante diversas em seus respectivos contextos políticos. Enquanto o primeiro exerce um papel independente e central no sistema de separação de poderes brasileiro, o segundo é parte integral do Tribunal de Justiça da União Europeia. A relevância do advogado geral advém muito mais da qualidade de seu trabalho, que do seu status no direito constitucional europeu. Já em relação ao Ministério Público, ambos pontos cumulam-se: qualidade dos pareceres bem como status autônomo e poderes garantidos constitucionalmente.

\section{REFERÊNCIAS}

ANÍBAL, Sérgio. Tribunal europeu deixa BCE mais à vontade para começar a comprar dívida pública. Público, Portugal, 14 jan. 2015. Disponível em: <https://www.publico.pt/economia/noticia/tribunaleuropeu-deixa-bce-mais-a-vontade-para-comecar-a-comprar-dividapublica-1682164>. Acesso em: 01 de julho de 2016. 
ARNULL, Anthony. The European Union and its Court of Justice. Nova York, NY: Oxford University Press, 2006.

BERMANN, George; PICARD, Etienne (ed.). Introduction to French Law. Alphen aan den Rijn: Kluwer Law International, 2008.

CHALMERS, Damiam; TOMKINS, Adam. European Union Public Law: Texts and Materials. Cambridge: Cambridge University Press, 2007.

CHURCH, Clive; DARDANELLI, Paolo. Twelve Key Points about Swiss Politics and Democracy, 2008. Disponível em: < $<$ https://pt.scribd.com/document/311856858/Twelve-Key-Points $>$. Acesso em: 07 de julho de 2016.

CRAIG, Paul; BÚRCA, Gráinne de. EC Law: Text, Cases, and Materials. Oxford: Clarendon Press, 1996.

EU Law: Text, Cases, and Materials. $4^{\mathrm{a}}$ ed. Oxford:

Oxford University Press, 2008.

_ EU Law: Text, Cases and Materials. $5^{\mathrm{a}}$ ed. Oxford:

Oxford University Press, 2011

DIETRICH, Andreas; WANZENRIED, Gabrielle. What determines the profitability of commercial banks? New evidence from Switzerland, 2009. Disponível em:

$<$ http://citeseerx.ist.psu.edu/viewdoc/download?doi=10.1.1.498.7051\&re $p=$ rep1\&type $=p d f>$. Acesso em: 04 de outubro de 2016.

FARIA, Luis Gustavo Joaquim de. A atuação do BNDES no Brasil e do KFW na Alemanha: uma comparação. Disponível em: $<$ http://s3.amazonaws.com/acadex.articles/Articles/56e5d94a8e0106b55d b67706-fileIdentified.pdf $>$. Acesso em: 04 de outubro de 2016. 
FELD, Lars; KIRCHGÄSSNER, Gebhard. Direct Democracy, Political Culture, and the Outcome of Economic Policy: a Report on The Swiss Experience. European Journal of Political Economy, Vol. 16, 2, 2000.

FELD, Lars; MATSUSAKA, John. Budget Referendums and Government Spendind: Evidende from Swiss Cantons. Journal of Public Economics, Vol. 87, 12, 2003. Disponível em: $<$ http://citeseerx.ist.psu.edu/viewdoc/download?doi=10.1.1.130.325\&rep $=$ rep1\&type=pdf $>$. Acesso em: 04 de outubro de 2016.

GILLIÉRON, Gwaladys. Public Prosecutors in the United States and Europe: A Comparative Analysis with Special Focus on Switzerland, France and Germany. Monografia (Graduação em Direito). Faculdade de Direito da Universidade de Zurique, Zurique, 2013.

GREAVES, Rosa. The first Advocate General, Maurice Lagrange. In: BURROWS, Noreen; GREAVES, Rosa: The Advocate General and EC Law. Oxford: Oxford University Press, 2009. Disponível em: $<$ http://www.oxfordscholarship.com/view/10.1093/acprof:oso/978019929 9003.001.0001/acprof-9780199299003-chapter-4>. Acesso em: 23 de junho de 2016.

HINAREJOS, Alicia. Judicial Control in the European Union: Reforming Jurisdiction in the Intergovernmental Pillars. New York, NY: Oxford University Press, 2009.

LENAERTS, Koen; MASELIS, Ignace; GUTMAN, Katheleen. EU Procedural Law. Oxford: Oxford University Press, 2014.

LODGE, Juliet. The European Community and the Challenge of the Future. $2^{\mathrm{a}}$ ed. Basingstone: Palgrave Macmillan, 1993. 
MAZZILLI, Hugo Nigro. Introdução ao Ministério Público. São Paulo, SP: Saraiva, 2015.

PAULO, Vicente; ALEXANDRINO, Marcelo. Direito Constitucional Descomplicado. São Paulo, SP: Método, 2010.

PORTO, Pedro Rui da Fontoura. Ministério Público Brasileiro: História de Uma Luta Institucional. Associação do Ministério Público Brasileiro do Estado do Rio de Janeiro: Princípios Institucionais do Ministério Público, 2013. Disponível em:

$<$ http://www.amperj.org.br/emails/MinisterioPublicobrasileiro.pdf $>$. Acesso em: 30 de janeiro de 2017.

ROBERTSON, Struan. How often does the ECJ follow Advocates General? Or should that be CJEU? Out-Law, Inglaterra, 18 out. 2010. Disponível em: $<$ http://www.out-law.com/page-11458>. Acesso em: 01 de julho de 2016.

SAMPAIO, José Adércio Leite. In: Joaquim José Gomes Canotilho; Gilmar Ferreira Mendes; Ingo Wolfgang Sarlet; Lenio Luiz Streck. Comentários à Constituição do Brasil. São Paulo, SP:

Saraiva/Almedina, 2013.

SESTER, Peter. The Opinion of the Advocate General on the Announced Bond-Buying Program of the ECB. CapLaw: Swiss Capital Markets Law, No. 34, 2015. Disponível em: <http://www.caplaw.ch/2015/theopinion-of-the-advocate-general-on-the-announced-bond-buyingprogram-of-the-ecb/>. Acesso em: 04 de outubro de 2016.

SHANY, Yuval. Assessing the Effectiveness of International Courts. Oxford: Oxford University Press, 2014, p. 277. Disponível em: $<$ http://www.oxfordscholarship.com/view/10.1093/acprof:oso/978019964 3295.001.0001/acprof-9780199643295? rskey $=$ Bfp8Hc\&result=3>. Acesso em: 30 de janeiro de 2017. 
SHAPIRO, Martin. Courts, a comparative and political analysis.

Chicago: University of Chicago Press, 1986.

TRIDIMAS, Takis. The Role of the Advocate General in the Development of Community Law: Some Reflections. Common Market Law Review, Vol. 34. 6, 1997, p. 1349-1387. Disponível em:

$<$ https://www.kluwerlawonline.com/abstract.php?area=Journals\&id=157 630>. Acesso em: 04 de outubro de 2016.

O Ministério Público Brasileiro e o Advogado Geral do Tribunal de Justiça da União Europeia: Uma Breve Comparação The Brazilian Ministério Público and the Advocate General of the Court of Justice of the European Union: a Brief Comparison

Submetido em: 2016-11-21

Aceito em: 2017-01-30 